http://dx.doi.org/00000.00/zootaxa.0000.0.0

http://zoobank.org/urn:lsid:zoobank.org:pub:00000000-0000-0000-0000-00000000000

\title{
Checklist of lizards and amphisbaenians of Argentina: an update
}

\author{
LUCIANO JAVIER AVILA ${ }^{1}$, LORENA ELIZABETH MARTINEZ \& MARIANA MORANDO \\ CENPAT-CONICET. Boulevard Almirante Brown 2915, U9120ACD, Puerto Madryn, Chubut, Argentina. \\ E-mail:avila@cenpat.edu.ar,morando@cenpat.edu.ar \\ ${ }^{\text {I}}$ Corresponding author.E-mail: avila@cenpat.edu.ar
}

\begin{abstract}
We update the list of lizards of Argentina, reporting a total of 261 species from the country, arranged in 27 genera and 10 families. Introduced species and dubious or erroneous records are discussed. Taxonomic, nomenclatural and distributional comments are provided when required. Considering species of probable occurrence in the country (known to occur in Bolivia, Brazil, Chile and Paraguay at localities very close to the Argentinean border) and still undescribed taxa, we estimate that the total number of species in Argentina could exceed 300 in the next few years.
\end{abstract}

Key words: Reptiles, Liolaemus, Phymaturus, South America, list

\section{Resumen}

Actualizamos la lista de lagartijas de la Argentina, presentamos un total de 261 especies para el país, organizados en 27 géneros y 10 familias. Especies introducidas, registros dudosos o erróneos son discutidos. Comentarios taxonómicos, nomenclaturales o de distribución son incorporados si son requeridos. Considerando especies de probable existencia en nuestro país (que se encuentran en Bolivia, Brasil, Chile y Paraguay en localidades muy cercanas al límite con Argentina) y taxas aún no descriptos, estimamos que el número total de especies en Argentina puede exceder las 300 en los próximos años.

Palabras clave: Reptiles, Liolaemus, Phymaturus, America del Sur, Lista

\section{Introduction}

The Republic of Argentina, situated in the southernmost portion of the South American Continent, occupies over $2.791 .810 \mathrm{~km}^{2}$ not including the Antarctic territory (www.ign.gob.ar). The country ranges from subtropical areas $\left(21^{\circ} 46^{\prime} \mathrm{S}\right)$ to subantartic regions $\left(55^{\circ} 03^{\prime} \mathrm{S}\right)$, extending latitudinally over about $3,400 \mathrm{~km}$, and about $1,400 \mathrm{~km}$ wide at its widest point. It possesses significant latitudinal and altitudinal variation ( $33^{\circ}$ of latitudinal range), and heights from Bajo de San Julian in Santa Cruz province at $105 \mathrm{~m}$ below sea level, up to Aconcagua Mountain at $6.959 \mathrm{~m}$ above sea level; as well as two gradients of physical variation, extending in north-south and east-west directions. Argentina presents a wide range of climates and soil types, being one the countries with greatest diversity of biogeographical units and ecosystems, including three main bioregions, Southern South America, Eastern South America, and the Central Andes, and 18 different ecoregions (Dinerstein et al. 1995). This diversity of environments harbors a high variety of lizard species, a few with large geographic distributions but the majority are endemic to Argentina; and a high number of species with restricted geographic distributions.

Since Cei's $(1986 ; 1993)$ monographs on the reptiles of Argentina, there has been a remarkable growth in the number of researchers working on lizards of the country, and a corresponding increase in knowledge of the lizard herpetofauna. Avila et al. (2000) presented an updated checklist as part of a categorization of lizards and amphisbaenians, but the species number has continued to grow markedly, particulary in the genera Liolaemus and 
Phymaturus. Many new species have been described, and the definition of many species and the taxonomic status and nomenclature of others have changed. This prompted an elaboration of a new list presented at the VII Congreso Argentino de Herpetología that took place in Corrientes city in 2006 (Avila et al. 2006a). This list was quickly outof-date, thus we continued gathering information for the publication of an updated list that was first published in the Web (Avila et al. 2011a), and a more updated version is presented here. In both checklists we try to summarize all new information available since Avila et al. (2000), and the cut-off date for this report is 21 January 2013. As Rivas et al. (2012) point: "Checklists are dynamic and should be considered as a still frame in time that has no lasting value, only showing the state of knowledge at a peculiar moment. Reports of new species, synonymisations and elevation of old synonyms to specific status, clarification of prior mistakes and new data about species distributions rapidly change our knowledge of biological diversity in tropical countries". Although the list will surely continue to grow during the next months and years, we consider it appropriate to present an updated publication that can be used by the scientific community as well as by those dedicated to conservation and natural resources management.

\section{Material and methods}

Information was updated from the last review (Avila et al., 2000) with additions of new published information and reviews (total or partial) of specimens deposited in the following collections: LJAMM-CNP (Luciano Javier Avila Mariana Morando Herpetological Collection, Centro Nacional Patagónico, Puerto Madryn, Argentina), MACN (Museo Argentino de Ciencias Naturales, Buenos Aires, Argentina), CENAI/CHINM (Centro Nacional de Investigaciones Iologicas/Coleccion Herpetologica Instituto Nacional de Microbiologia, now deposited in Museo Argentino de Ciencias Naturales, Buenos Aires, Argentina), MLP (Museo de La Plata, La Plata, Argentina ), JMCDC (Jose Miguel Cei-Diagnostic Collection, Universidad Nacional de San Luis, Argentina), MVZ (Museum of Vertebrate Zoology, Berkeley, USA), MCZ (Museum of Comparative Zoology, Harvard, USA), KU (Natural History Museum, Kansas University, Lawrence, USA), FMNH (Field Museum of Natural History, Chicago, USA), BYU (Monte L. Bean Life Science Museum, Brigham Young University, Provo, USA), FML (Fundación Miguel Lillo, San Miguel de Tucumán, Argentina), IMCN-UNSJ (Instituto y Museo de Ciencias Naturales, Universidad Nacional de San Juan, Argentina), NMNH (National Museum of Natural History, Smithsonian Institution, Washington, DC, USA), MHN (Museo de Historia Natural de San Rafael, Argentina), IADIZA-CH (CCTMendoza-CONICET, Mendoza, Argentina), MHN-SR-H (Museo Provincial de Ciencias Naturales Florentino Ameghino, Santa Fe, Argentina), IBA-UNC (Instituto de Biología Animal, Universidad Nacional de Cuyo, Mendoza, Argentina), UNRC-ZV (Universidad Nacional de Río Cuarto, Río Cuarto, Argentina), UNNE (Universidad Nacional del Nordeste, Corrientes, Argentina), RVP (Relevamiento de Vertebrados de La Pampa, Museo de Ciencias Naturales de La Pampa, Santa Rosa, Argentina). We gathered published information that included new species descriptions and/or geographic distributions, and included of these in the References section (we assume that bibliography published before 2,000 was already included in that publication). Information taken from bibliographic sources can be ordered into three main categories:

a) Revisionary studies of specific genera or species complexes, including: Diplolaemus (Cei et al. 2003; Victoriano et al. 2010), Liolaemus and/or Phymaturus (Abdala 2007a; Avila et al. 2006b; Morando et al. 2003, 2004, 2007, 2008; Lobo \& Quinteros 2005a,b; Pincheira-Donoso et al. 2008, Breitman et al. 2011a, 2012), Pristidactylus (Cei et al. 2001), Stenocercus (Torrez-Carvajal 2007), and Urostrophus and Anisolepis (Etheridge \& Williams 1991);

b) Checklists of some species/subspecies complexes and new geographic citations, including: Ameiva ameiva (Cabrera 2002), Amphisbaena plumbea (Avila et al. 2007a), Anisolepis grillii (Alvarez 2000), A. longicauda (Waller 2009), Cnemidophorus lacertoides (Federico 2000; Pérez \& Grassini 2001), C. longicauda (Pérez \& Petracchi 2004, Frutos et al. 2005), C. serranus (Pérez et al. 2004; Arias \& Lobo 2005), C. tergolaevigatus (Cabrera \& Etheridge 2006), Diplolaemus darwinii (Ibargüengoytía \& Schulte 2001), Homonota andicola (Acosta \& Blanco 2001), H. fasciata (Pérez et al. 2008; Etchepare et al. 2011), H. underwoodi (Pérez et al. 2005), patagonian Liolaemus (Avila et al. 2001; 2004a), L. chiliensis (Christie 2002a), L. bibronii (Pérez \& Pérez 2001), L. buergeri (Abdala \& Robles 2007), L. ditadai (Abdala 2007b), L. donosobarrosi (Abdala \& Juarez 2006), L. fitzgeraldi (Acosta et al. 2000, Avila 2004), L. fitzingerii (Avila et al. 2007b), L. goetschi (Nori et al. 2010a), L. 
grosseorum (Avila et al. 2002), L. hermannunezi (Abdala \& Quinteros 2007), L. inacayali (Avila et al. 2006c), L. josei (Frutos et al. 2008), L. laurenti (Abdala et al. 2007), L. lentus (Pérez \& Avila 2011), L. lineomaculatus (Ibargüengoytía et al. 2001, Christie 2002b), L. loboi (Abdala \& Lobo 2006a), northwestern Liolaemus (Díaz Gómez 2007), L. olongasta (Sanabria et al. 2005), L. petrophilus (Avila et al. 2006c), L. pictus (Avila et al. 2006c), L. pseudoanomalus (Avila et al. 2003a), L. punmahuida (Avila \& Pérez 2006), L. puritamensis (Quinteros \& Abdala 2007), L. riojanus (Acosta \& Murua, 2000), L. silvanae (Abdala \& Díaz Gómez, 2001), L. somuncurae (Avila et al. 2007c), L. tenuis (Christie \& Sage 2002), L. umbrifer (Abdala \& Lobo 2007), L. uspallatensis (Buff et al. 2001), L. xanthoviridis (Minoli \& Avila 2011a), L. yanalcu (Lobo \& Lobo, 2003), L. wiegmannii (Parraga 2011), Aspronema dorsivittatum (Williams \& Kacoliris 2011), Ophiodes intermedius (Herrera et al. 2001), Phymaturus verdugo (Abdala \& Juarez 2007; Avila et al. 2007d), Pristidactylus achalensis (Salas et al. 2004), Pristidactylus nigroiugulus (Avila et al. 2003b; Minoli \& Avila 2011b), Teius suquiensis (Cabrera \& Monguillot 2007), Tupinambis rufescens (Acosta \& Gomez 2000), and Vanzosaura rubricauda (Aguirre \& Céspedes 2001).

c) Citations included in descriptions of new species (see new species in Table 2), including: Abdala (2002, 2003, 2005a,b), Abdala and Díaz Gómez (2006), Abdala and Lobo (2006b,c), Abdala and Quinteros (2008), Abdala et al. (2008, 2009, 2010, 2011, 2012a,b), Avila (2003), Avila et al. (2003c, 2004b, 2007e, 2008, 2009, 2010a,b, 2011b, 2012a,b,c, 2013), Breitman et al. (2011b, c), Cabrera and Monguillot (2006), Cabrera (2012), Corbalán et al. (2009), Espinoza et al. (2000), Espinoza and Lobo (2003), Quinteros (2012), Quinteros et al. (2008a,b), Laspiur et al. (2007), Lobo and Espinoza (2004), Lobo and Abdala (2007), Lobo et al. (2010a, 2012a,b,c), Martínez et al. (2011), Martinez Oliver and Lobo (2002), Monguillot et al. (2006), Montero and Cespedez (2002), Nori et al. (2010b), Pincheira-Donoso and Scolaro (2007), Pincheira-Donoso et al. (2007), Quinteros and Abdala (2011), Scolaro and Cei (2003), Scolaro and Cei (2006), Scolaro and Ibargüengoytía (2007), Scolaro et al. (2008), Scolaro and Ibargüengoytía (2008), Scolaro and Tappari (2009), Scolaro and PincheiraDonoso (2010), Scolaro et al. (2012), Vega et al. (2008).

Publications of lists of species inhabiting some protected natural areas, geographic units, or selected phytogeographic regions, like Chaco National Park (Céspedez et al. 2001), Patagonia (Scolaro 2005, 2006), chacoan Mar Chiquita (Briguera et al. 2005), all National Parks (Chebez et al. 2005), Impenetrable Great Chaco (Kacoliris et al. 2006a), Buenos Aires coastal dunes (Kacoliris et al. 2006b), San Guillermo Reserve San Juan (Acosta et al. 2007), oriental Chaco (Alvarez et al. 2009), Ischigualasto Provincial Park (Sanabria \& Quiroga 2009), small private reserves as in Scrocchi and Giraudo (2005), Lopez and Kubisch (2008), Lopez and Prado (2008), or checklists of political geographic units of Argentina, as San Luis province (Avila \& Carrizo 2003; Guerreiro et al. 2005), Entre Ríos province (Gimenez et al. 2008), Mendoza province (Corbalán \& Debandi 2008), Córdoba (Cabrera 2009), Chaco, Formosa and Corrientes (Alvarez et al. 2002), Río Negro province (Scrocchi et al. 2010; Pérez et al. 2011), Misiones (Lopez \& Prado 2012), La Rioja (Cruz et al. 2012); general books such as Chebez $(2008,2009)$ were used only when they included voucher information.

For the genera and species we follow the classification used by Townsend et al. (2011) for iguanians, Gamble et al. (2008) for gekkos, Hedges and Conn (2012) for skinks, and for all other lizards, Vitt and Caldwell (2009). We do not include introduced species in the tables or list, but we comment about the species registered for Argentina below. We also present species names and their known geographic distributions in tables by provinces (Table 1); we use a "?" when the species was cited and not registered again, or if we have doubts about the presence of the species in the province. We do not discuss nomenclatural or systematic status that are well developed in other publications, the validity of species names, and any higher taxonomic rank above family, since lizard classification has been under debate during the last years and a consensus has not been reached yet. Comments about some species are made in the appropriate sections.

\section{Results}

Results are presented as a species checklist, in a table (Table 1), and a map (Fig. 1) with the presence of each species by province, and a table (Table 2) showing the differences with the previous Checklist of Avila et al. (2000). 


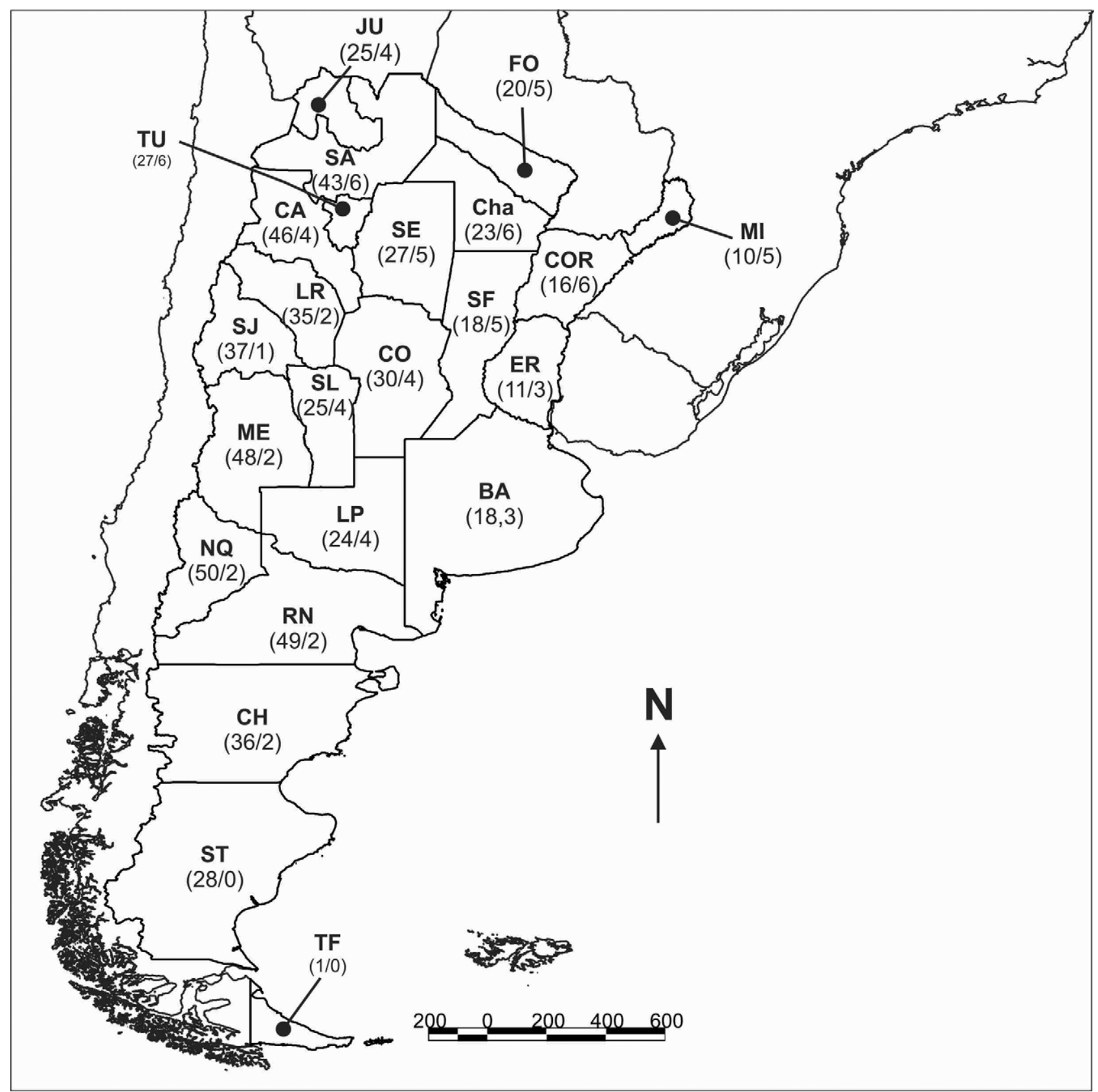

FIGURE 1. Map showing the number of species of lizards and amphisbaenians in each province of Argentina; in brackets, number of lizards / amphisbaenians. BA = Buenos Aires, $\mathrm{CA}=$ Catamarca, Cha $=$ Chaco, $\mathrm{CO}=\mathrm{Cordoba}, \mathrm{CH}=\mathrm{Chubut}$, $\mathrm{COR}$ $=$ Corrientes, $\mathrm{ER}=$ Entre Rios, FO = Formosa, JU = Jujuy, LP = La Pampa, LR = La Rioja, ME = Mendoza, MI = Misiones, $\mathrm{NQ}=$ Neuquen, RN = Rio Negro, SA = Salta, SJ = San Juan, SL = San Luis, ST = Santa Cruz, SF = Santa FE, SE = Santiago del Estero, TF $=$ Tierra del Fuego, TU = Tucuman.

\section{Checklist}

\section{Polychrotidae Fitzinger, 1843}

Polychrus Cuvier, 1817

Polychrus acutirostris (Spix, 1825) 


\section{Leiosauridae Frost et al., 2001}

Anisolepis Boulenger, 1885

Anisolepis grillii Boulenger, 1891

Anisolepis longicauda (Boulenger, 1891)

Urostrophus Duméril \& Bibron, 1837

Urostrophus gallardoi Etheridge \& Williams, 1991

Diplolaemus Bell, 1843

Diplolaemus bibronii Bell, 1843

Diplolaemus darwinii Bell, 1843

Diplolaemus leopardinus (Werner, 1898)

Diplolaemus sexcinctus Cei, Scolaro \& Videla, 2003

Pristidactylus Fitzinger, 1843

Pristidactylus achalensis (Gallardo, 1964)

Pristidactylus araucanus (Gallardo, 1964)

Pristidactylus casuhatiensis (Gallardo, 1968)

Pristidactylus fasciatus (D’Orbigny \& Bibron, 1837)

Pristidactylus nigroiugulus Cei et al., 2001

Pristidactylus scapulatus (Burmeister, 1861)

Leiosaurus Duméril \& Bibron, 1837

Leiosaurus bellii Duméril \& Bibron, 1837

Leiosaurus catamarcensis Koslowsky, 1898

Leiosaurus jaguaris Laspiur, Acosta \& Abdala, 2007

Leiosaurus paronae (Peracca, 1897)

\section{Tropiduridae Bell, 1843}

Stenocercus Duméril \& Bibron, 1837

Stenocercus caducus (Cope, 1862)

Stenocercus doellojuradoi (Freiberg, 1944)

Stenocercus marmoratus (Duméril \& Bibron, 1837)

Stenocercus pectinatus (Duméril \& Bibron, 1837)

Stenocercus roseiventris D'Orbigny in Duméril \& Bibron, 1837

Tropidurus Wied, 1824

Tropidurus etheridgei Cei, 1982

Tropidurus melanopleurus Boulenger, 1902

Tropidurus spinulosus (Cope, 1862)

Tropidurus torquatus (Wied-Neuwied, 1820)

Liolaemidae Frost et al., 2001/Liolaemini Schulte et al., 2004

Liolaemus (Wiegmann, 1834)

Liolaemus abaucan Etheridge, 1993

Liolaemus abdalai Quinteros, 2012

Liolaemus albiceps Lobo \& Laurent, 1995

Liolaemus andinus Koslowsky, 1895

Liolaemus anomalus Koslowsky, 1896

Liolaemus antumalguen Avila, Morando, Pérez \& Sites, 2010

Liolaemus araucaniensis Müller \& Hellmich, 1932

Liolaemus archeforus Donoso-Barros \& Cei, 1971 
Liolaemus austromendocinus Cei, 1974

Liolaemus avilae Breitman, Parra, Pérez \& Sites, 2011

Liolaemus azarai Avila, 2003

Liolaemus baguali Cei \& Scolaro, 1983

Liolaemus bibronii (Bell, 1843)

Liolaemus bitaeniatus Laurent, 1984

Liolaemus boulengeri Koslowsky, 1898

Liolaemus buergeri Werner, 1907

Liolaemus burmeisteri Avila, Pérez, Medina, Sites \& Morando, 2012

Liolaemus calchaqui Lobo \& Kretzschmar, 1996

Liolaemus camarones Abdala, Díaz Gómez \& Heredia, 2012

Liolaemus canqueli Cei, 1975

Liolaemus caparensis Breitman, Pérez, Parra, Morando, Sites \& Avila, 2012

Liolaemus capillitas Hulse, 1979

Liolaemus casamiquelai Avila, Pérez, Morando \& Sites, 2010

Liolaemus cazianiae Lobo, Slodki \& Valdecantos, 2010

Liolaemus ceii Donoso-Barros, 1971

Liolaemus chacabucoense Nuñez \& Scolaro, 2009

Liolaemus chacoensis Shreve, 1948

Liolaemus chaltin Lobo \& Espinoza, 2004

Liolaemus chehuachekenk Avila, Morando \& Sites, 2008

Liolaemus chiliensis (Lesson, 1830)

Liolaemus chillanensis Müller \& Hellmich, 1932

Liolaemus chlorostictus Laurent, 1991

Liolaemus choique Abdala, Quinteros, Scrocchi \& Stazzonelli, 2010

Liolaemus cinereus Monguillot, Acosta, Cabrera \& Villavicencio, 2006

Liolaemus coeruleus Cei \& Ortíz, 1983

Liolaemus crepuscularis Abdala \& Díaz Gómez, 2006

Liolaemus cuyanus Cei \& Scolaro, 1980

Liolaemus cuyumhue Avila, Morando, Pérez, \& Sites, 2009

Liolaemus cyaneinotatus Martinez, Avila, Pérez, Pérez, Sites \& Morando, 2011

Liolaemus cyanogaster (Duméril \& Bibron, 1837)

Liolaemus darwinii (Bell, 1843)

Liolaemus diaguita Abdala, Quinteros, Arias, Portelli \& Palavecino, 2011

Liolaemus dicktracyi Espinoza \& Lobo, 2003

Liolaemus ditadai Cei, 1983

Liolaemus donosobarrosi (Cei, 1974)

Liolaemus dorbignyi Koslowsky, 1898.

Liolaemus duellmani Cei, 1978

Liolaemus dumerili Abdala, Semhan, Moreno-Azocar, Bonino, Paz \& Cruz, 2012

Liolaemus eleodori Cei, Etheridge \& Videla, 1983

Liolaemus elongatus Koslowsky, 1896

Liolaemus escarchadosi Scolaro \& Cei, 1997

Liolaemus espinozai Abdala, 2005

Liolaemus exploratorum Cei \& Williams, 1984

Liolaemus famatinae Cei, 1980

Liolaemus fitzgeraldi Boulenger, 1899

Liolaemus fitzingerii (Duméril \& Bibron, 1837)

Liolaemus flavipiceus Cei \& Videla, 2003

Liolaemus gallardoi Cei \& Scolaro, 1982

Liolaemus goetschi Müller \& Hellmich, 1938

Liolaemus gracielae Abdala, Acosta, Cabrera, Villavicencio \& Marinero, 2009 
Liolaemus gracilis (Bell, 1843)

Liolaemus gravenhorsti (Gray, 1845)

Liolaemus griseus Laurent, 1984

Liolaemus grosseorum Etheridge, 2001

Liolaemus gununakuna Avila, Morando, Pérez \& Sites, 2004

Liolaemus halonastes Lobo, Slodki \& Valdecantos, 2010

Liolaemus hatcheri Stejneger, 1909

Liolaemus heliodermis Espinoza, Lobo, \& Cruz, 2000

Liolaemus hermannunezi Pincheira-Donoso, Scolaro \& Schulte II, 2007

Liolaemus huacahuasicus Laurent, 1985

Liolaemus huayra Abdala, Quinteros \& Espinoza, 2008

Liolaemus inacayali Abdala, 2003

Liolaemus inti Abdala, Quinteros \& Espinoza, 2008

Liolaemus irregularis Laurent, 1986

Liolaemus josei Abdala, 2005

Liolaemus kingii (Bell, 1843)

Liolaemus kolengh Abdala \& Lobo, 2006

Liolaemus koslowskyi Etheridge, 1993

Liolaemus kriegi Müller \& Hellmich, 1939

Liolaemus laurenti Etheridge, 1992

Liolaemus lavillai Abdala \& Lobo, 2006

Liolaemus lemniscatus (Gravenhorst, 1838)

Liolaemus lentus (Gallardo, 1966)

Liolaemus lineomaculatus (Boulenger, 1885)

Liolaemus loboi Abdala, 2003

Liolaemus magellanicus (Hombron \& Jacquinot, 1847)

Liolaemus mapuche Abdala, 2002

Liolaemus martorii Abdala, 2003

Liolaemus melanops Burmeister, 1888

Liolaemus montanezi Cabrera \& Monguillot, 2006

Liolaemus montanus Koslowsky, 1898

Liolaemus morandae Breitman, Parra, Pérez \& Sites, 2011

Liolaemus morenoi Etheridge \& Christie, 2003

Liolaemus multicolor Koslowsky, 1898

Liolaemus multimaculatus Duméril \& Bibron, 1837

Liolaemus neuquensis Müller \& Hellmich, 1939

Liolaemus nigriceps (Philippi, 1860)

Liolaemus olongasta Etheridge, 1993

Liolaemus orientalis Müller, 1924

Liolaemus orko Abdala \& Quinteros, 2008

Liolaemus ornatus Koslowsky, 1898

Liolaemus pagaburoi Lobo \& Espinoza, 1999

Liolaemus parvus Quinteros, Abdala, Díaz Gómez \& Scrocchi, 2008

Liolaemus petrophilus Donoso-Barros \& Cei, 1971

Liolaemus pictus argentinus Müller \& Hellmich, 1939

Liolaemus poecilochromus Laurent, 1986

Liolaemus pseudoanomalus Cei, 1981

Liolaemus puelche Avila, Morando, Pérez \& Sites, 2007

Liolaemus pulcherrimus Laurent, 1992

Liolaemus puna Lobo \& Espinoza, 2004

Liolaemus punmahuida Avila, Pérez \& Morando, 2003

Liolaemus puritamensis Nuñez \& Fox, 1989 
Liolaemus purul Abdala, Semhan, Moreno-Azocar, Bonino, Paz \& Cruz, 2012

Liolaemus pyriphlogos Quinteros, 2012

Liolaemus quilmes Etheridge, 1993

Liolaemus rabinoi (Cei, 1974)

Liolaemus ramirezae Lobo \& Espinoza, 1999

Liolaemus riojanus (Cei, 1979)

Liolaemus robertmertensi Hellmich, 1964

Liolaemus rothi Koslowsky, 1898

Liolaemus ruibali Donoso-Barros, 1961

Liolaemus sagei Etheridge \& Christie, 2003

Liolaemus salinicola Laurent, 1986

Liolaemus sanjuanensis Cei, 1982

Liolaemus sarmientoi Donoso Barros, 1973

Liolaemus saxatilis Avila, Acosta, Martori \& Cei, 1992

Liolaemus scapularis Laurent, 1982

Liolaemus scolaroi Pincheira-Donoso \& Núñez, 2005

Liolaemus scrocchii Quinteros, Abdala \& Lobo, 2008

Liolaemus senguer Abdala, 2005

Liolaemus shehuen Abdala, Díaz Gómez \& Heredia, 2012

Liolaemus shitan Abdala, Quinteros, Scrocchi \& Stazzonelli, 2010

Liolaemus silvanae (Donoso-Barros \& Cei, 1971)

Liolaemus sitesi Avila, Olave, Perez, Perez \& Morando, 2012

Liolaemus smaug Abdala, Quinteros, Scrocchi \& Stazzonelli, 2010

Liolaemus somuncurae Cei \& Scolaro, 1981

Liolaemus talampaya Avila, Morando, Pérez \& Sites, 2004

Liolaemus tandiliensis Vega, Bellagamba \& Lobo, 2008

Liolaemus tari Scolaro \& Cei, 1997

Liolaemus tehuelche Abdala, 2003

Liolaemus telsen Cei \& Scolaro, 1999

Liolaemus tenuis tenuis (Duméril \& Bibron, 1837)

Liolaemus thermarum Videla \& Cei, 1996

Liolaemus tregenzai Pincheira-Donoso \& Scolaro, 2007

Liolaemus tristis Scolaro \& Cei, 1997

Liolaemus tromen Abdala, Semhan, Moreno Azocar, Bonino, Paz \& Cruz, 2012

Liolaemus tulkas Quinteros, Abdala, Díaz Gómez \& Scrocchi, 2008

Liolaemus umbrifer Espinoza \& Lobo, 2003

Liolaemus uptoni Scolaro \& Cei, 2006

Liolaemus uspallatensis Macola \& Castro, 1982

Liolaemus vallecurensis Pereyra, 1992

Liolaemus vulcanus Quinteros \& Abdala 2011

Liolaemus wiegmannii (Duméril \& Bibron, 1837)

Liolaemus xanthoviridis Cei \& Scolaro, 1980

Liolaemus yanalcu Martínez Oliver \& Lobo, 2002

Liolaemus zullyae Cei \& Scolaro, 1996

Phymaturus Gravenhorst, 1838

Phymaturus agilis Scolaro, Ibargüengoytia \& Pincheira-Donoso, 2008

Phymaturus antofagastensis Pereyra, 1985

Phymaturus calcogaster Scolaro \& Cei, 2003

Phymaturus castillensis Scolaro \& Pincheira-Donoso, 2010

Phymaturus ceii Scolaro \& Ibargüengoytia, 2007

Phymaturus delheyi Avila, Pérez, Pérez \& Morando, 2011

Phymaturus denotatus Lobo, Nenda \& Slodki, 2012 
Phymaturus desuetus Scolaro \& Tappari, 2009

Phymaturus dorsimaculatus Lobo \& Quinteros, 2005

Phymaturus etheridgei Lobo, Abdala \& Valdecantos, 2010

Phymaturus excelsus Lobo \& Quinteros, 2005

Phymaturus extrilidus Lobo, Espinoza, Sanabria \& Quiroga, 2012

Phymaturus felixi Lobo, Abdala \& Valdecantos, 2010

Phymaturus gynechlomus Corbalán, Scolaro \& Debandi, 2009

Phymaturus indistinctus Cei \& Castro, 1973

Phymaturus laurenti Lobo, Abdala \& Valdecantos, 2010

Phymaturus mallimaccii Cei, 1980

Phymaturus manuelae Scolaro \& Ibargüengoytía, 2008

Phymaturus nevadoi Cei \& Roig, 1975

Phymaturus palluma (Bell, 1843)

Phymaturus patagonicus Koslowsky, 1898

Phymaturus payuniae Cei \& Castro, 1973

Phymaturus punae Cei, Etheridge \& Videla, 1983

Phymaturus querque Lobo, Abdala \& Valdecantos, 2010

Phymaturus roigorum Lobo \& Abdala, 2007

Phymaturus sinervoi Scolaro, Mendez de la Cruz \& Ibargüengoytía, 2012

Phymaturus sitesi Avila, Pérez, Pérez \& Morando, 2011

Phymaturus somuncurensis Cei \& Castro, 1973

Phymaturus spectabilis Lobo \& Quinteros, 2005

Phymaturus spurcus Barbour, 1921

Phymaturus tenebrosus Lobo \& Quinteros, 2005

Phymaturus verdugo Cei \& Videla, 2003

Phymaturus videlai Scolaro \& Pincheira-Donoso, 2010

Phymaturus zapalensis Cei \& Castro, 1973

\section{Phyllodactylidae Gamble et al. 2008}

Homonota (Gray, 1845)

Homonota andicola Cei, 1978

Homonota borellii (Peracca, 1897)

Homonota darwinii darwinii Boulenger, 1885

Homonota darwinii macrocephala Cei, 1978

Homonota fasciata (Duméril \& Bibron, 1836)

Homonota underwoodi Kluge, 1964

Homonota whitii Boulenger, 1885

Homonota williamsii Avila, Pérez \& Morando, 2012

Phyllopezus Peters, 1877

Phyllopezus pollicaris przewalskyi (Koslowsky, 1895)

\section{Amphisbaenidae Gray, 1825}

Amphisbaena Linnaeus, 1758

Amphisbaena angustifrons Cope, 1861

Amphisbaena bolivica Mertens 1929

Amphisbaena heterozonata Burmeister, 1861

Amphisbaena hiata Montero \& Céspedez (2002)

Amphisbaena mertensii Strauch, 1881 
Amphisbaena plumbea Gray, 1872

Amphisbaena prunicolor (Cope, 1885)

Anops Bell, 1833

Anops kingi Bell, 1833

Cercolophia Vanzolini, 1992

Cercolophia borelli (Peracca, 1897)

Leposternon Wagler, 1824

Leposternon microcephalum Wagler, 1824

\section{Gymnophthalmidae Merren 1820}

Cercosaura (Wagler, 1830)

Cercosaura ocellata Wagler, 1830

Cercosaura parkeri (Ruibal, 1952)

Cercosaura schreibersii schreibersii Wiegmann, 1834

Cercosaura steyeri (Tedesco, 1998)

Opipeuter Uzzell, 1969

Opipeuter xestus Uzzell, 1969

Vanzosaura Rodriguez, 1991

Vanzosaura rubricauda (Boulenger, 1902)

\section{Teiidae Gray, 1827}

Ameiva (Mayer, 1795)

Ameiva ameiva ameiva Linnaeus, 1758

Cnemidophorus (Wagler, 1830)

Cnemidophorus abalosi Cabrera, 2012

Cnemidophorus lacertoides Duméril \& Bibron, 1839)

Cnemidophorus leachei Peracca, 1897

Cnemidophorus longicaudus (Bell, 1843)

Cnemidophorus serranus Cei \& Martori, 1991

Cnemidophorus tergolaevigatus Cabrera, 2004

Kentropyx (Spix, 1825)

Kentropix lagartija Gallardo, 1962

Kentropix viridistriga (Boulenger, 1894)

Teius Merren, 1820

Teius oculatus (D’Orbigny \& Bibron, 1837)

Teius suquiensis Avila \& Martori, 1991

Teius teyou (Daudin, 1802)

Tupinambis (Daudin, 1802)

Tupinambis merianae (Duméril \& Bibron, 1839)

Tupinambis rufescens (Günther, 1871)

\section{Mabuyidae Mittleman, 1952}

Aspronema Hedges \& Conn, 2012

Aspronema dorsivittatum (Cope, 1862)

Notomabuya Hedges \& Conn, 2012

Notomabuya frenata (Cope, 1862) 


\section{Anguidae Gray, 1825}

Ophiodes Wagler, 1828

Ophiodes intermedius Boulenger, 1894

Ophiodes vertebralis (Bocourt, 1881)

Ophiodes fragilis Peters, 1877

\section{Taxonomic richness}

We recorded a total of 261 species, belonging to 10 families, and 27 genera of amphisbaenians and lizards in Argentina (Checklist and Table 1). Avila et al. (2000) listed 167 species, belonging to 8 families and 26 genera. Changes in number of families are related to nomenclatural rearragements, split of Polychrotidae in Polychrotidae and Leiosauridae (Frost et al. 2001) and split of Tropiduridae in Liolaemidae (or Liolaemini) and Tropiduridae (Frost \& Etheridge 1989, Frost et al. 2001); all Pantodactylus species found in Argentina are considered as members of Cercosaura (Doan 2003). Recently, Mabuya species from Argentina were allocated to two new genera, Aspronema and Notomabuya (Hedges \& Conn 2012)

The family Liolaemidae or the rank free clade Liolamini (our preferred option) contains almost $75 \%$ of the lizard species of Argentina, with 190 species (73\%), including two genera, Liolaemus with 156 species (60\%), and Phymaturus with 34 species $(13.0 \%)$. All other genera have fewer than 10 species. Comparisons between the previous checklist (Avila et al. 2000) and this work are presented in Table 2.

TABLE 1. Species of lizards and amphisbaenians by province.

\begin{tabular}{|c|c|c|c|}
\hline Genus & Avila et al. 2000 & This work & Variation \\
\hline Polychrus & 1 & 1 & 0 \\
\hline Anisolepis & 3 & 2 & -1 \\
\hline Urostrophus & 1 & 1 & 0 \\
\hline Diplolaemus & 3 & 4 & +1 \\
\hline Pristidactylus & 4 & 6 & +2 \\
\hline Leiosaurus & 3 & 4 & +1 \\
\hline Stenocercus & 6 & 5 & -1 \\
\hline Tropidurus & 4 & 4 & 0 \\
\hline Liolaemus & 90 & 156 & +66 \\
\hline Phymaturus & 10 & 34 & +24 \\
\hline Homonota & 7 & 8 & +1 \\
\hline Phyllopezus & 1 & 1 & 0 \\
\hline Amphisbaena & 7 & 7 & 0 \\
\hline Anops & 1 & 1 & 0 \\
\hline Cercolophia & 1 & 1 & 0 \\
\hline Leposternum & 1 & 1 & 0 \\
\hline Cercosaura & 1 & 4 & +3 \\
\hline Opipeuter & 1 & 1 & 0 \\
\hline Vanzosaura & 1 & 1 & 0 \\
\hline Ameiva & 1 & 1 & 0 \\
\hline Cnemidophorus & 5 & 6 & +1 \\
\hline Kentropyx & 2 & 2 & 0 \\
\hline Teius & 3 & 3 & 0 \\
\hline Tupinambis & 2 & 2 & 0 \\
\hline Mabuya (Aspronema + Notomabuya) & 2 & $2(1+1)$ & 0 \\
\hline Ophiodes & 3 & 3 & 0 \\
\hline
\end{tabular}




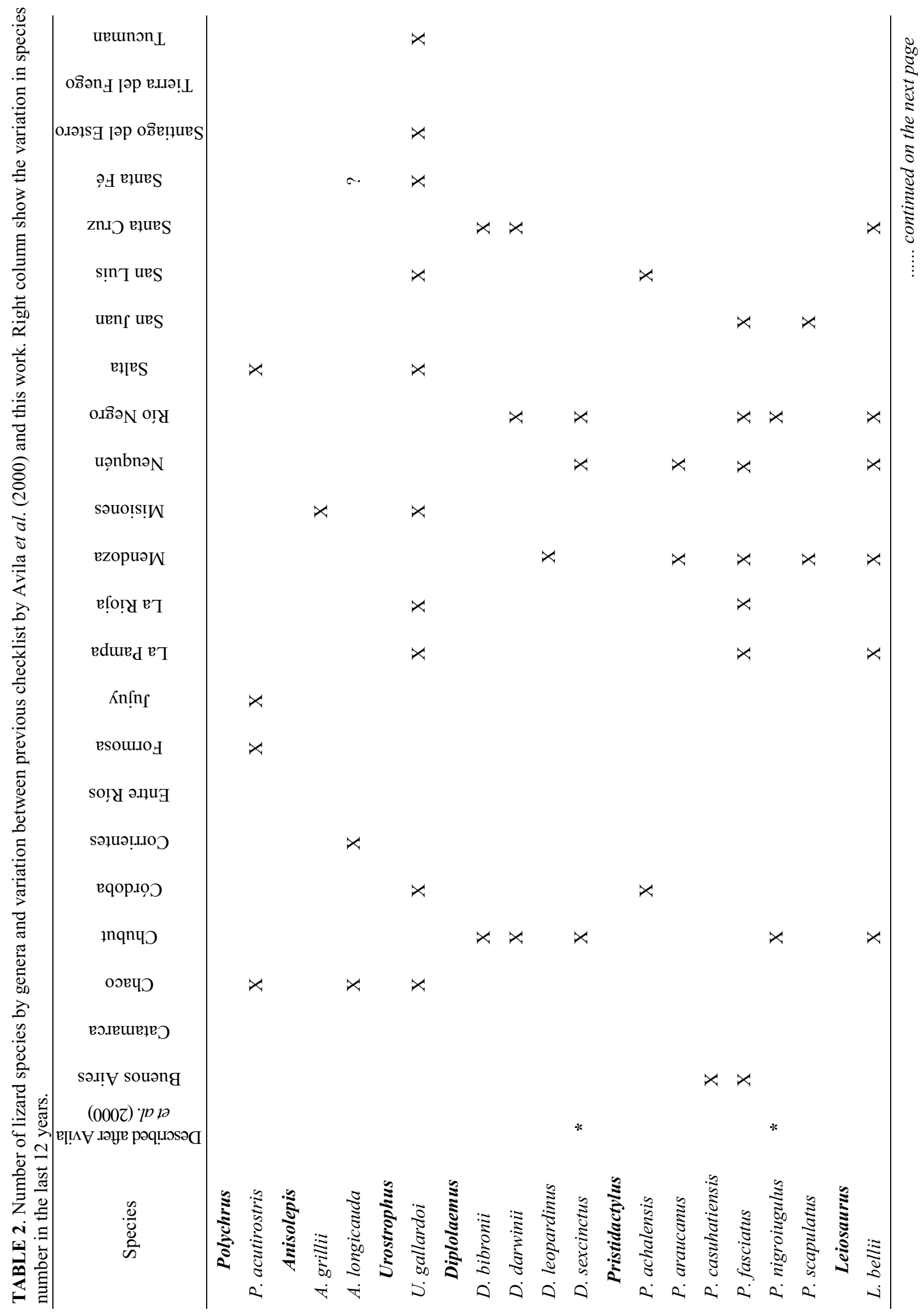




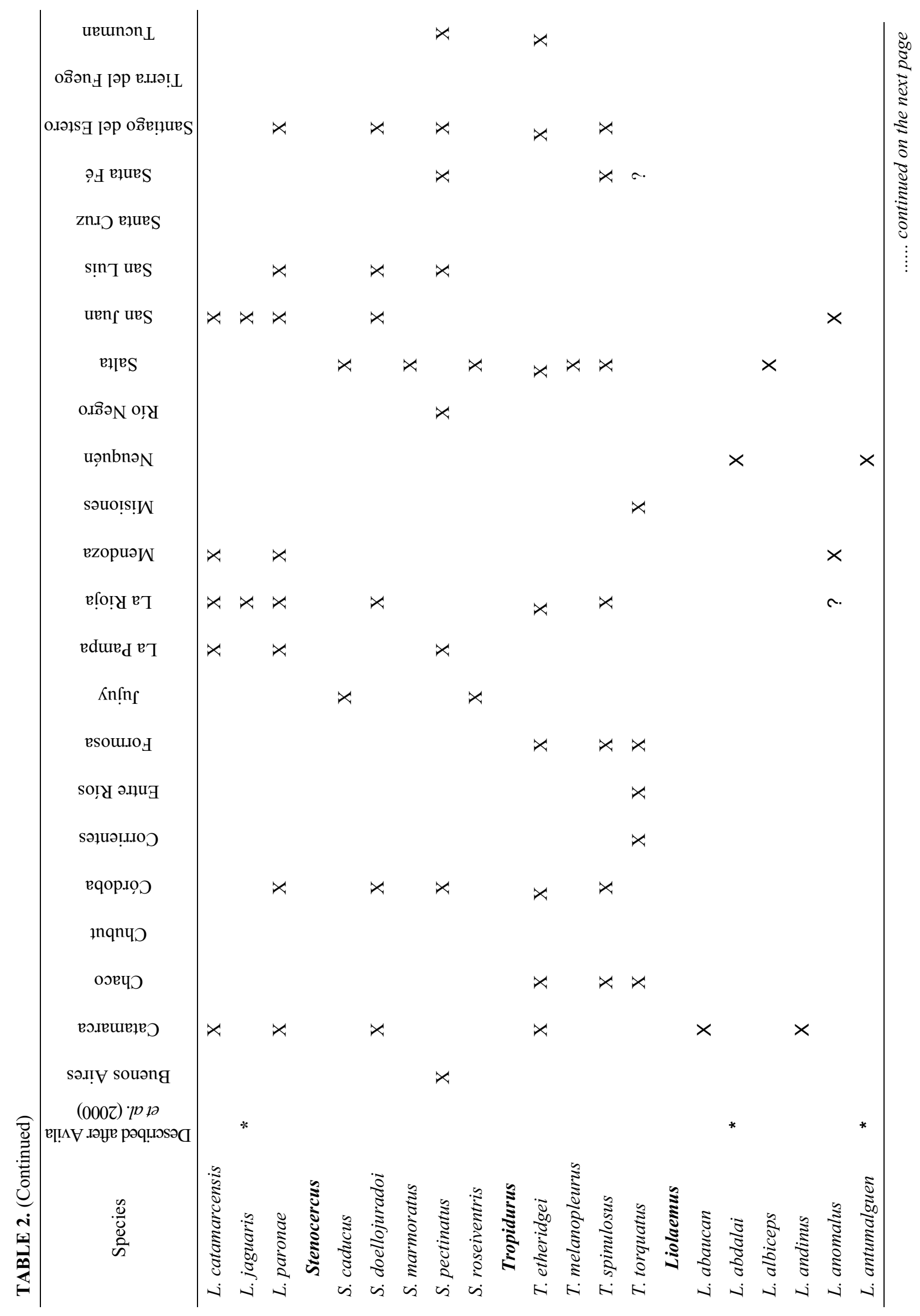

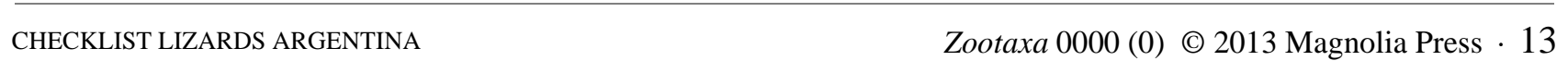




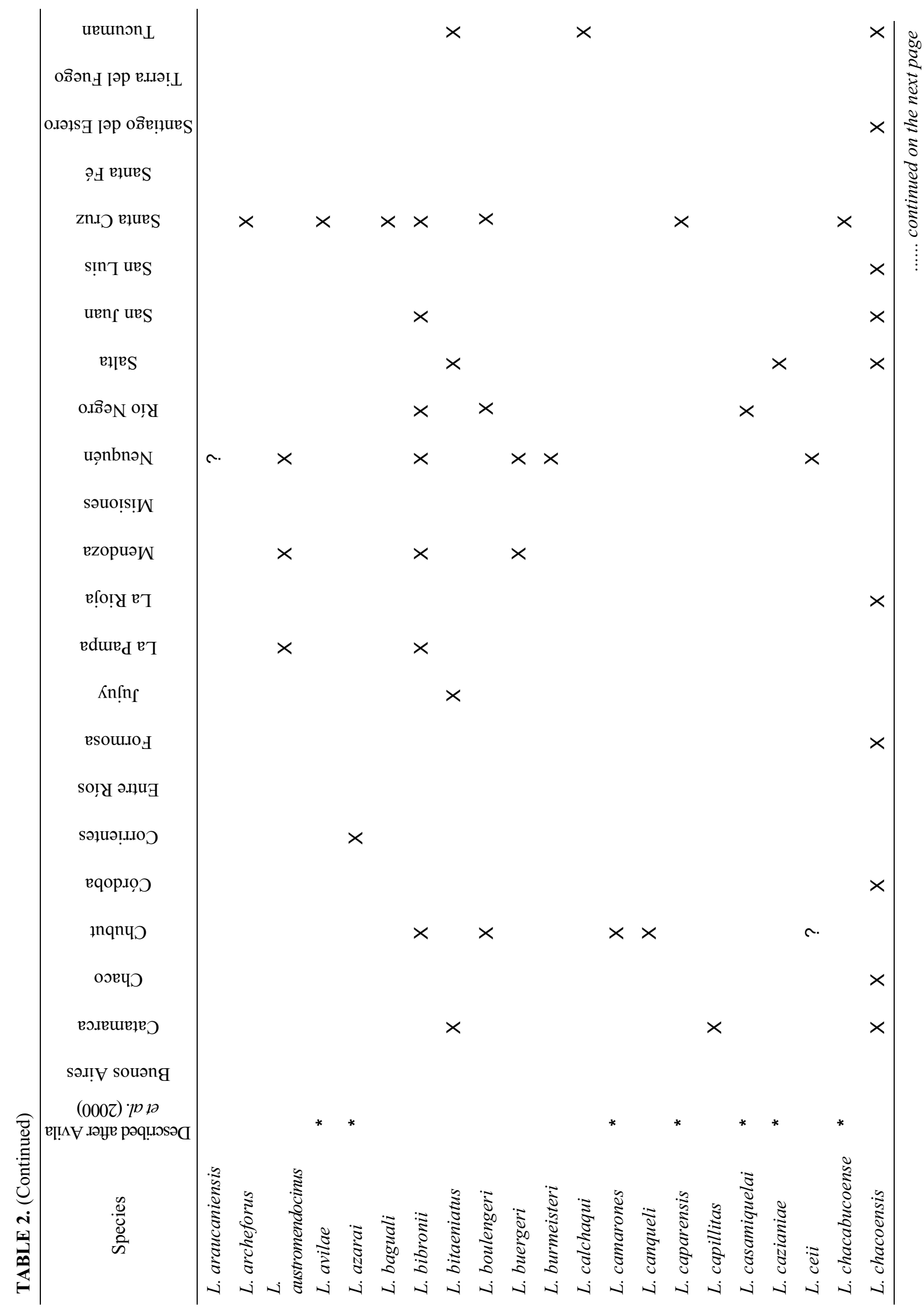




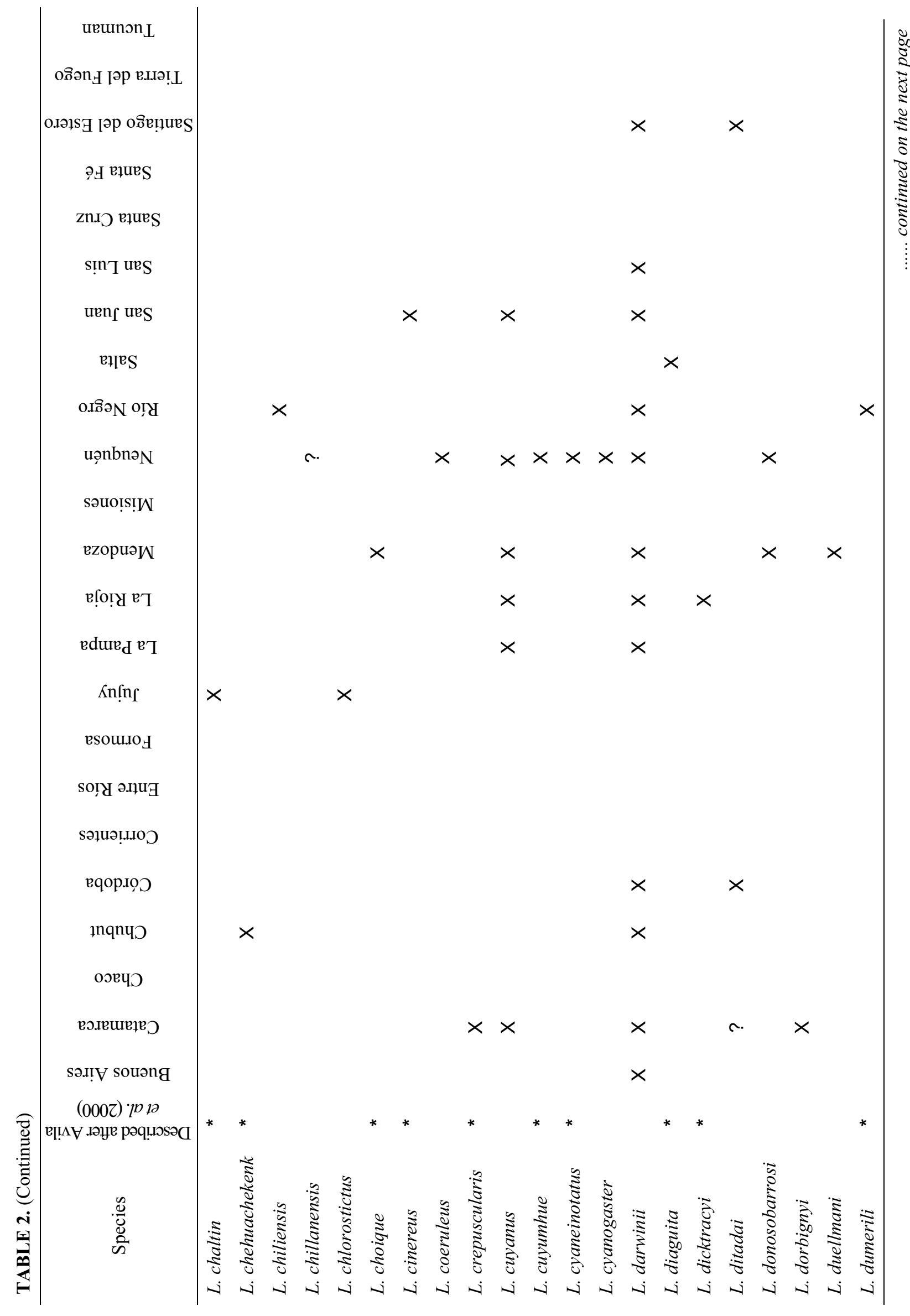




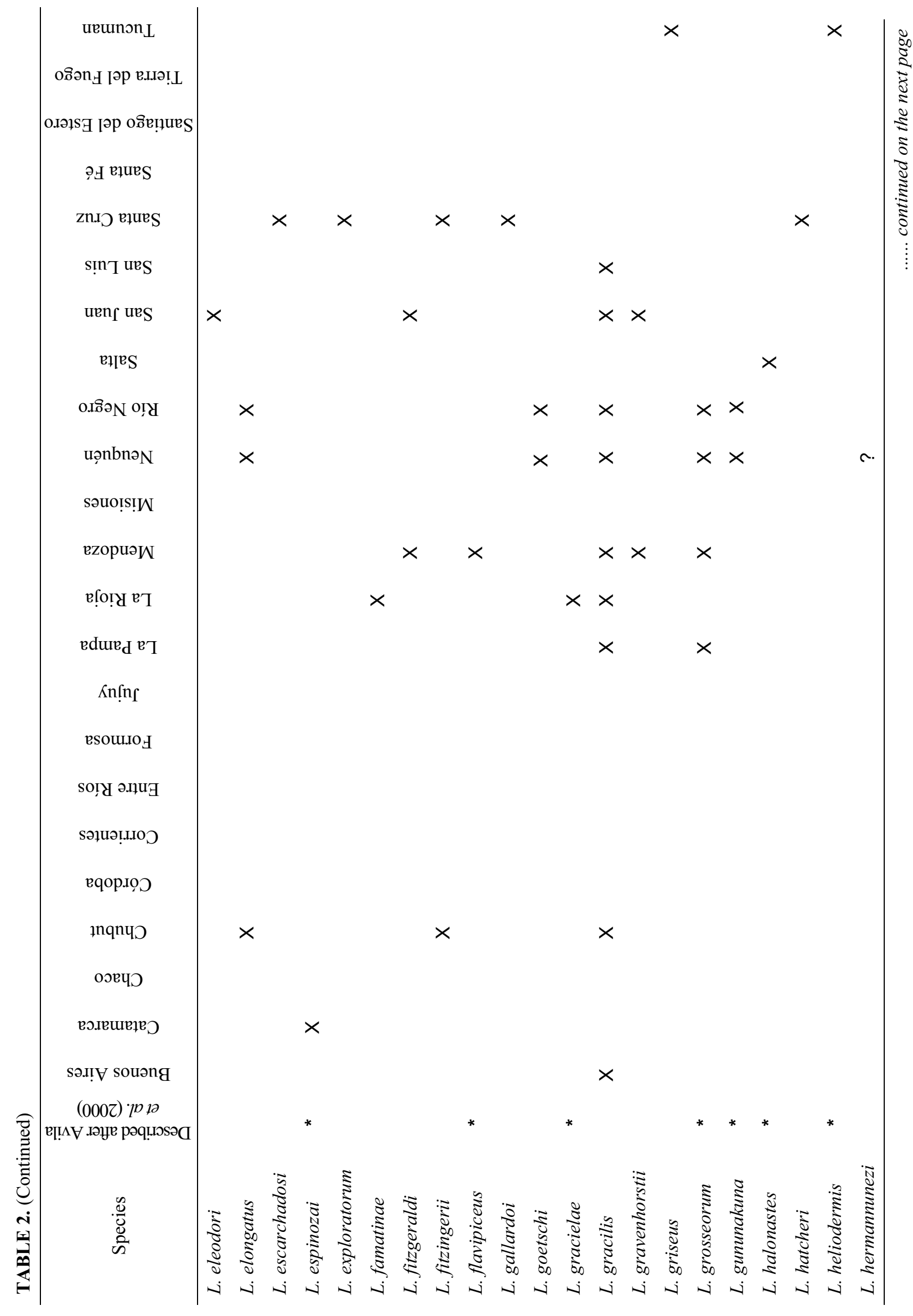




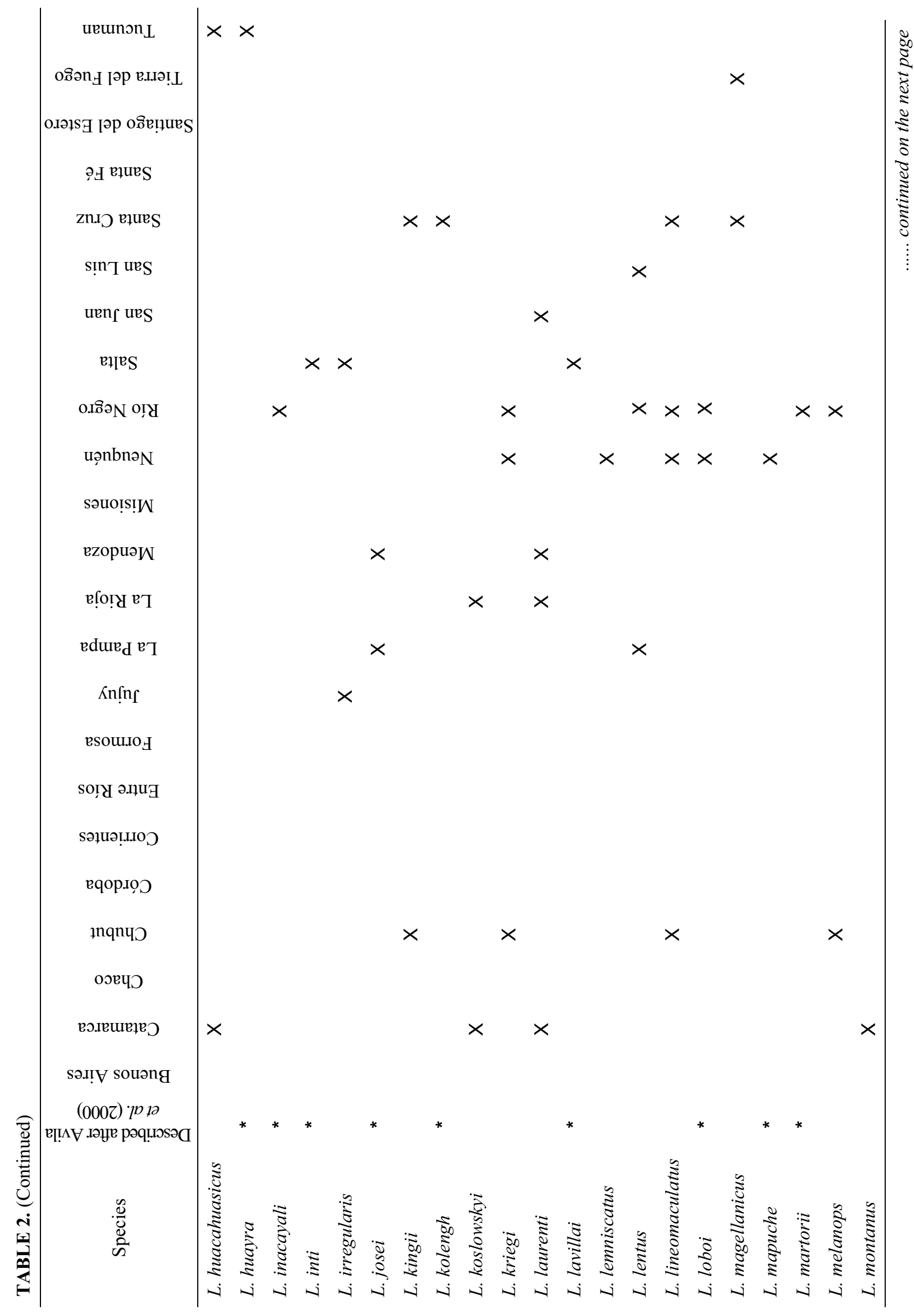




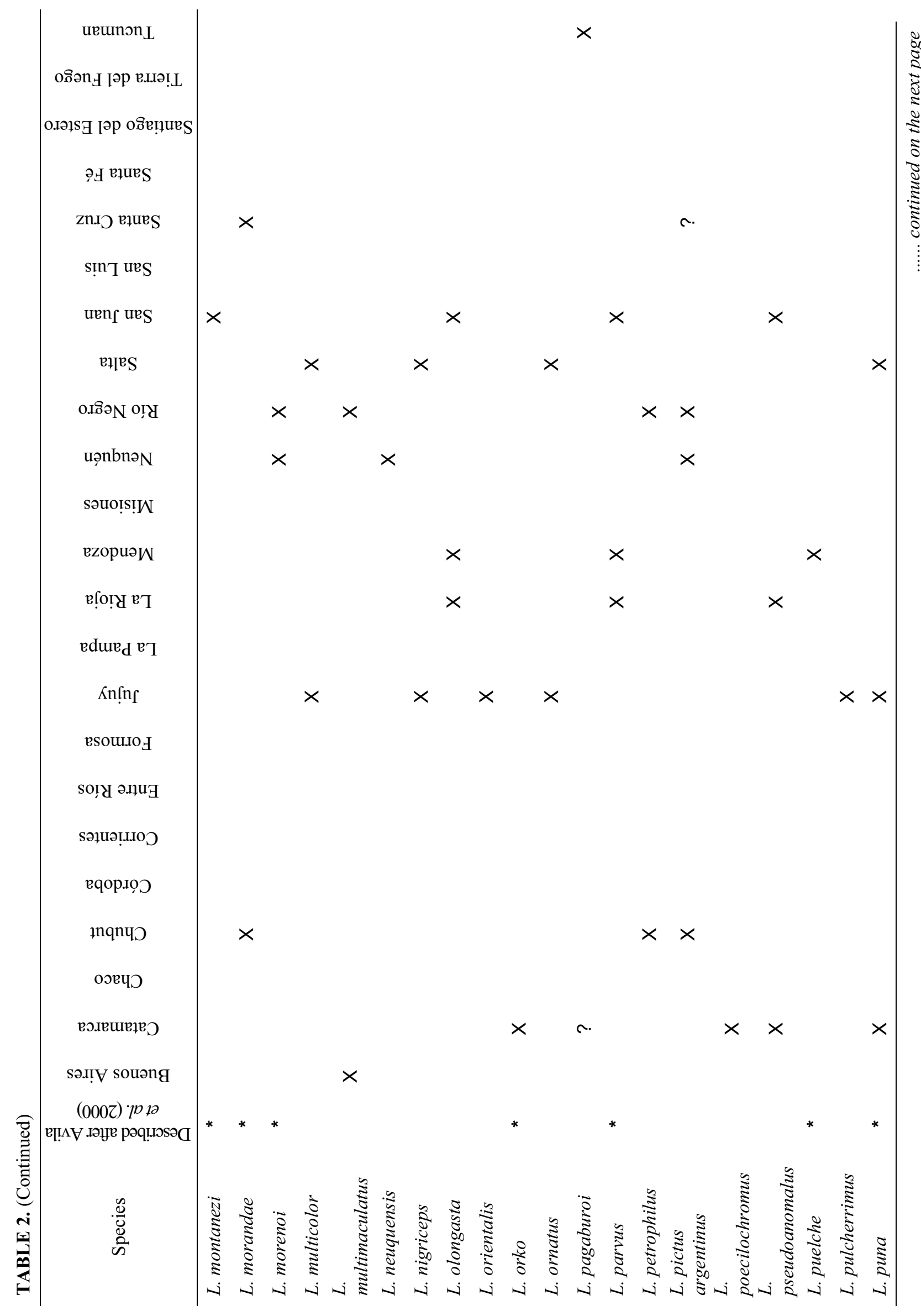




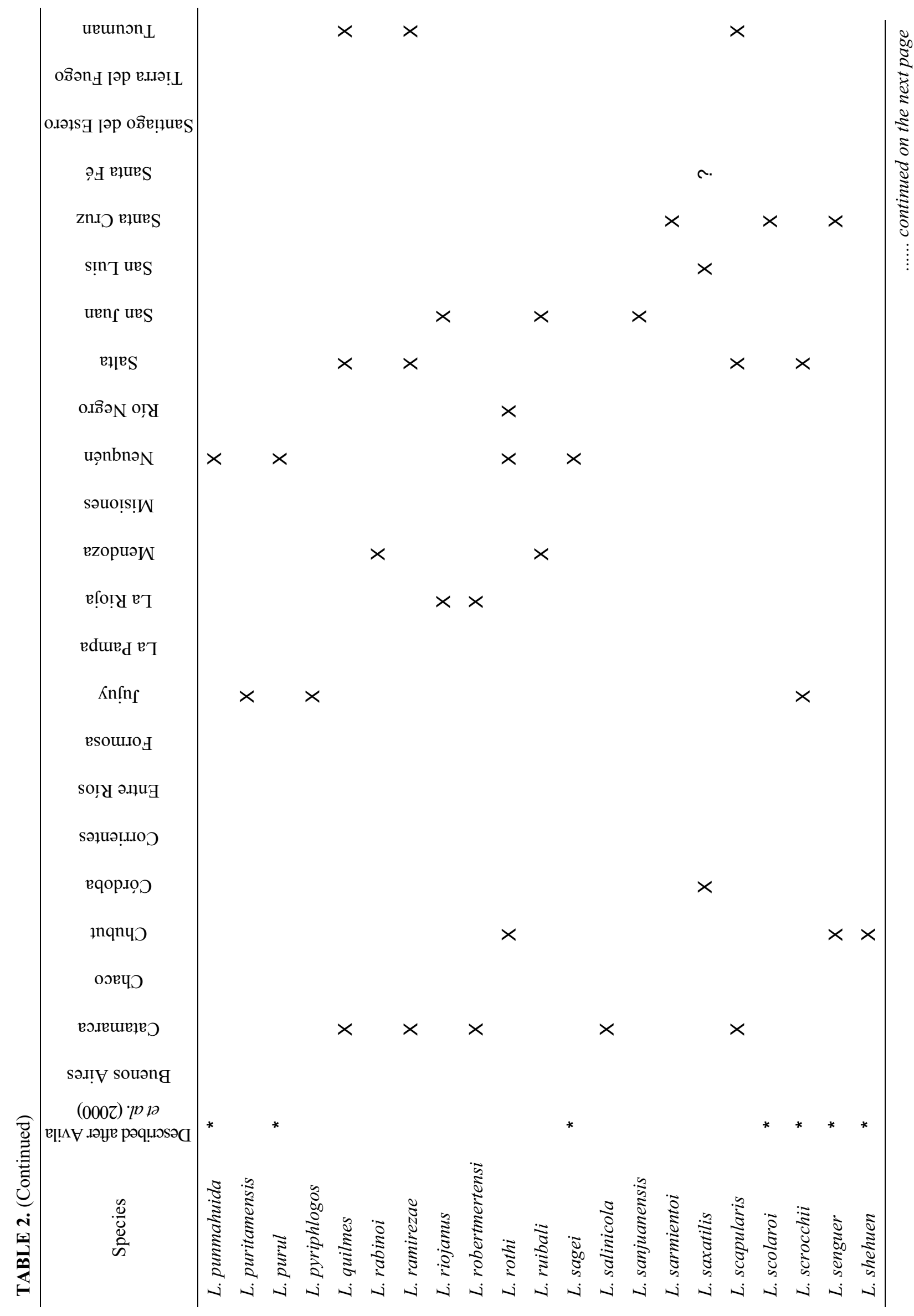




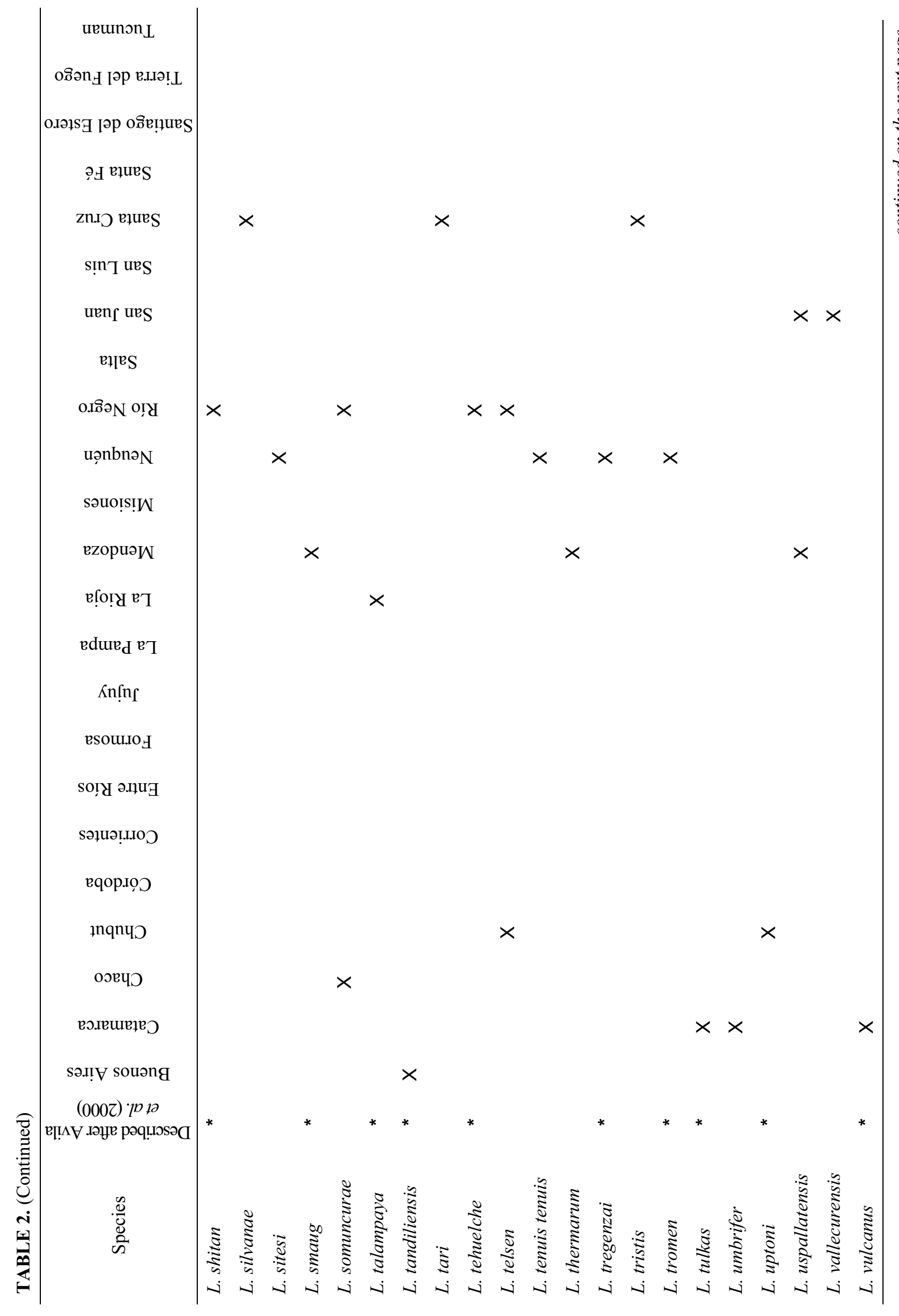




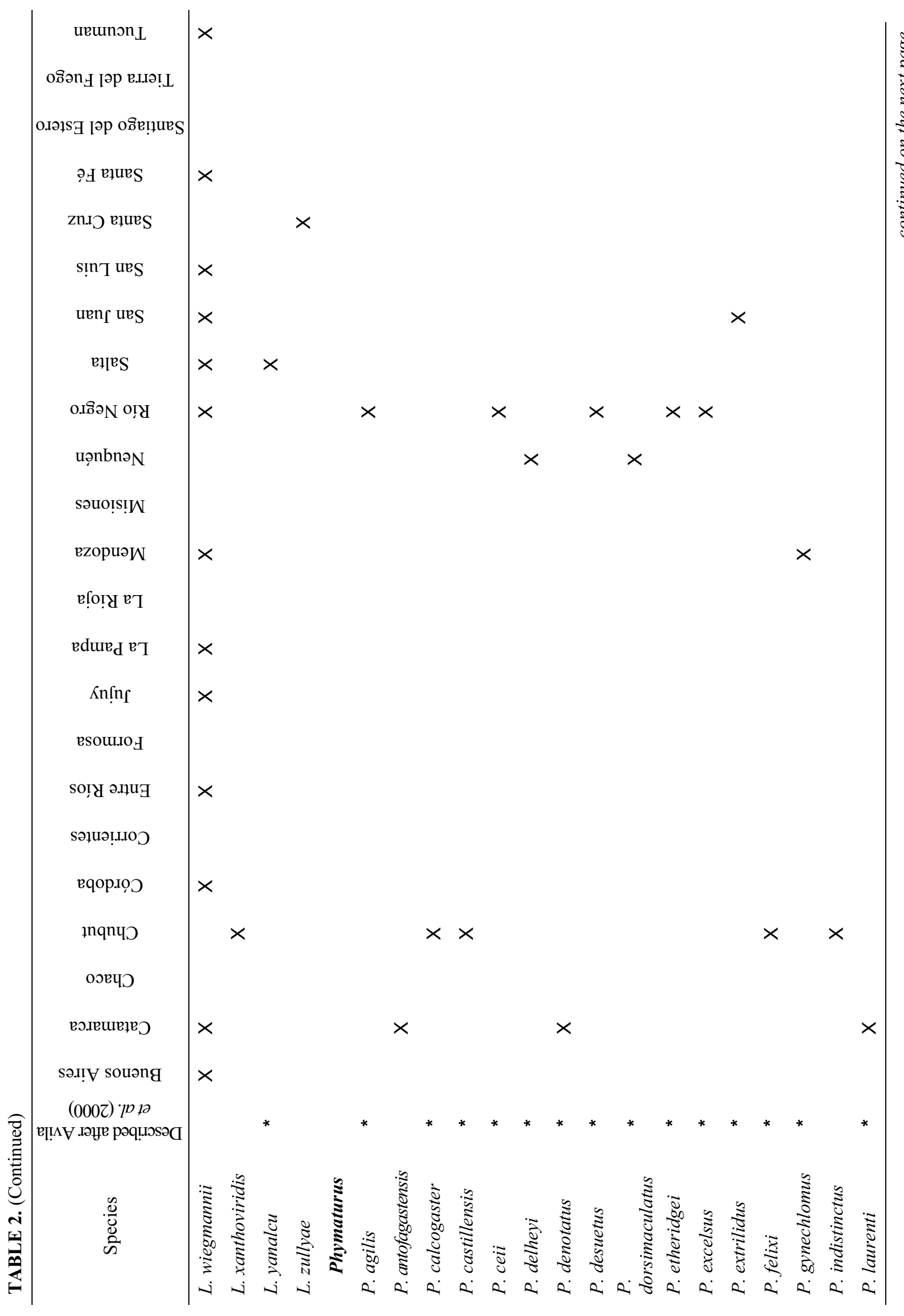




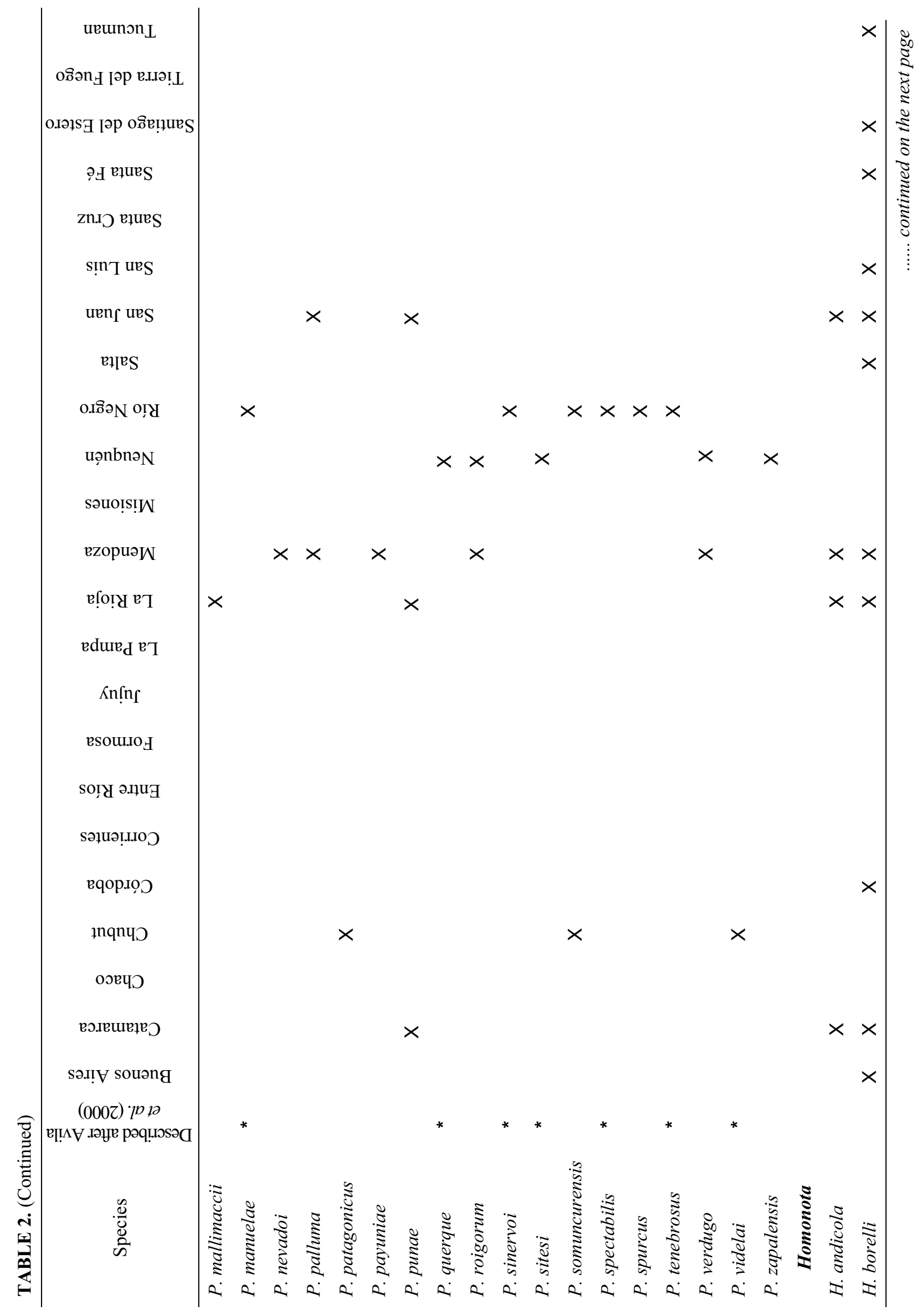




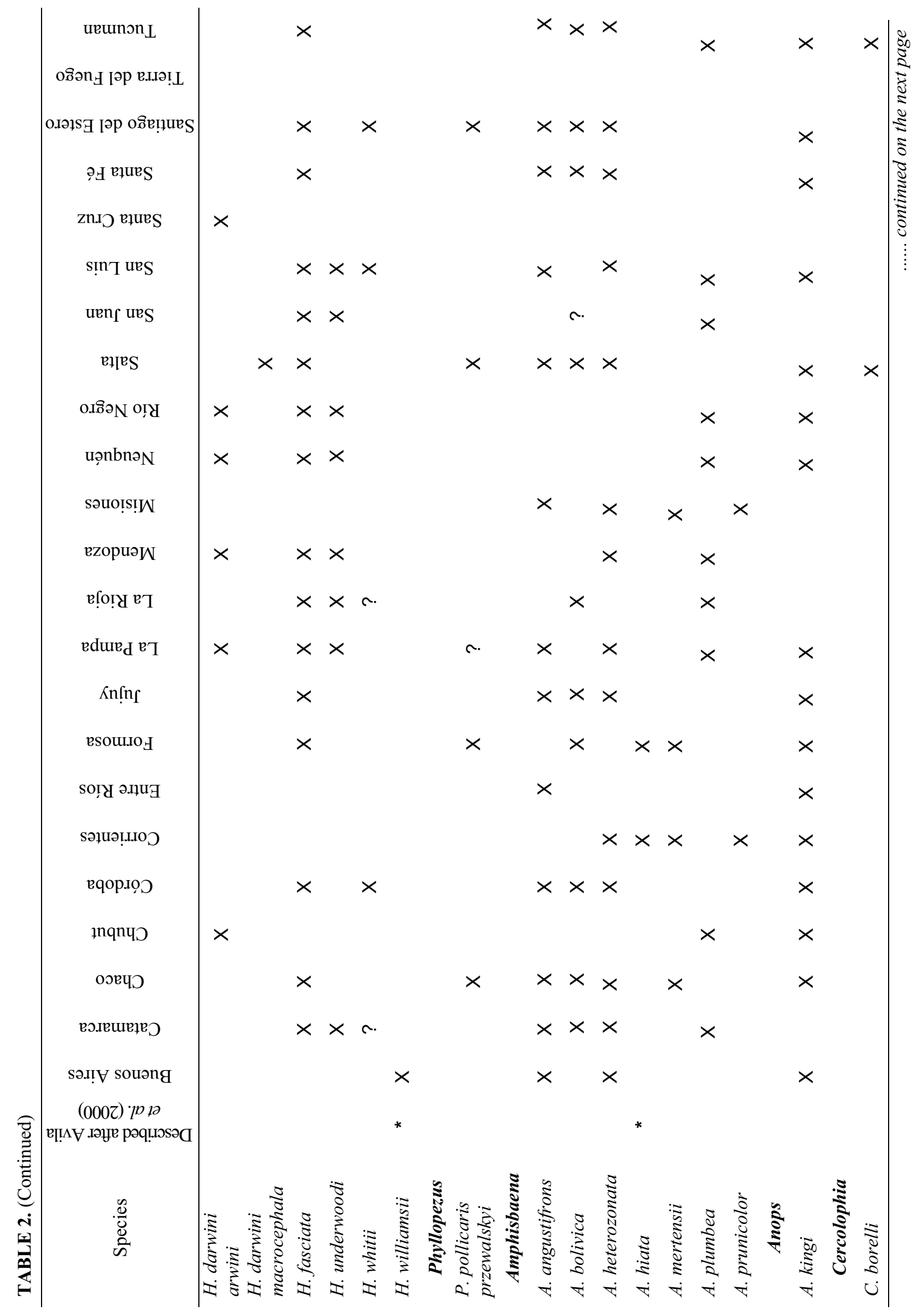




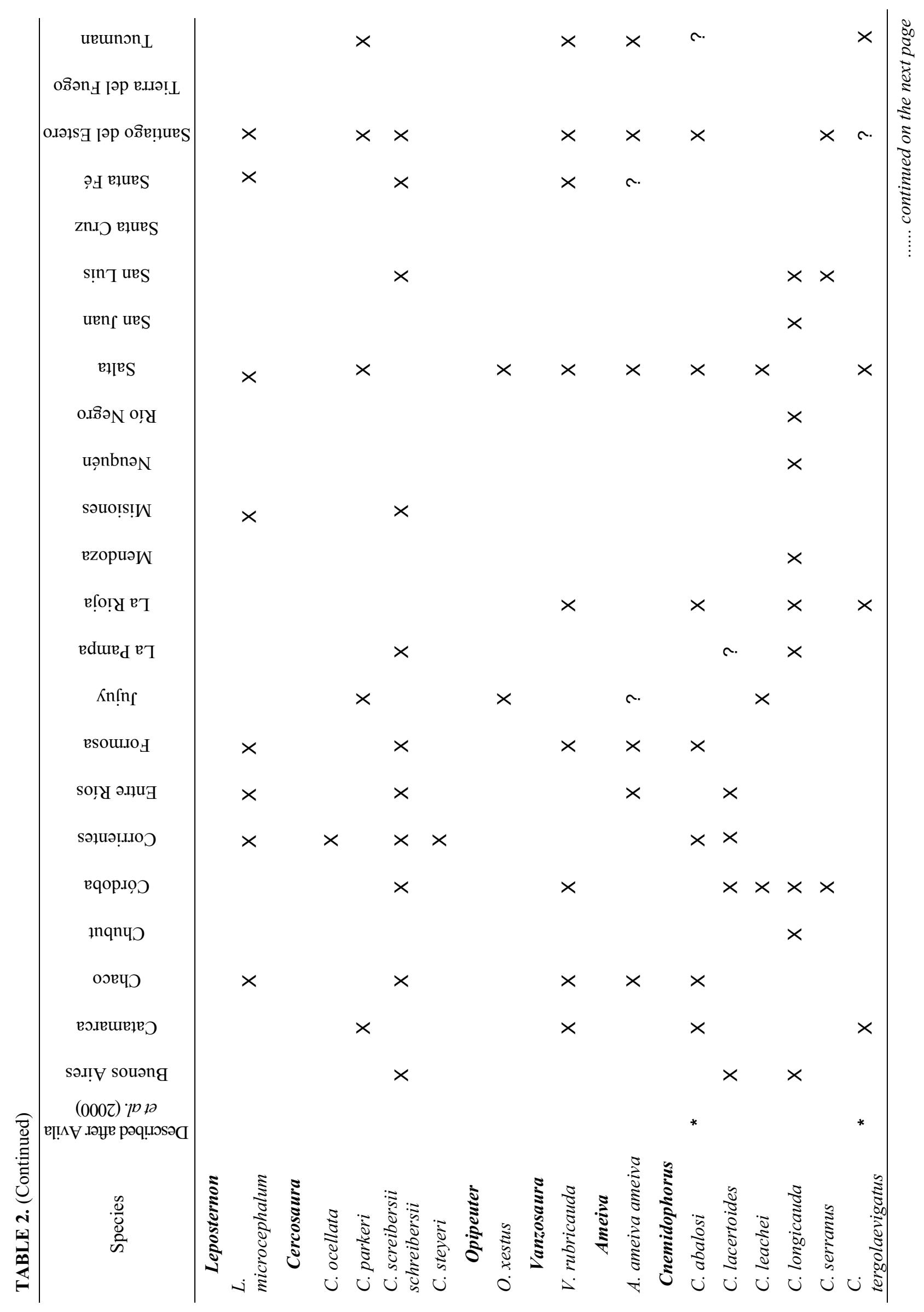




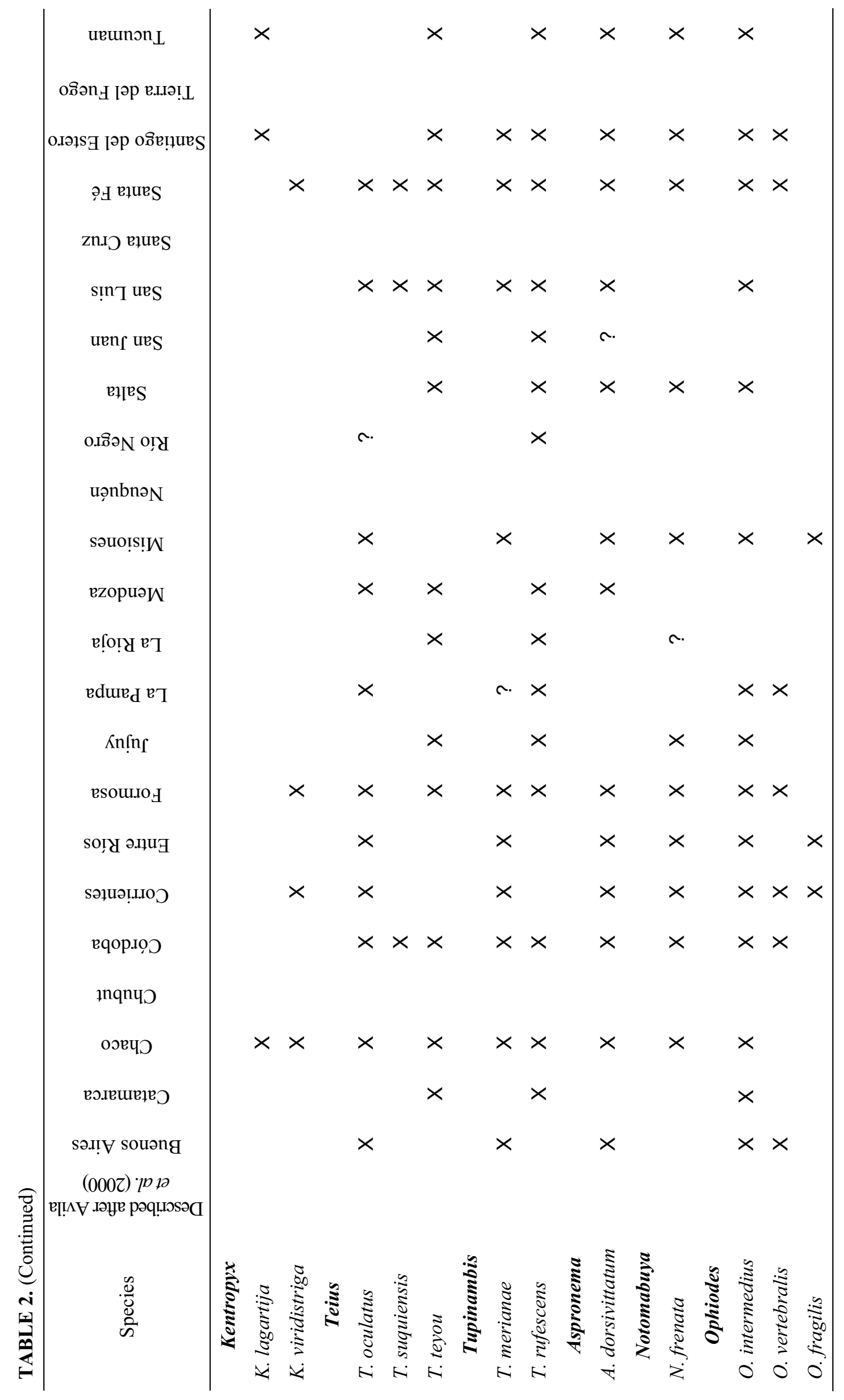




\section{Undescribed species}

Morando et al. (2003) using molecular data (mtDNA sequences) estimated that with future detailed studies, the total number of Liolaemus species could be around 320 (at that time there were 174 described species and the actual total number now is +238 ). Further, other detailed studies hypothesized several candidate species for some particular clades within this genus (e.g. Morando et al. 2004, 2007; Breitman et al. 2011a, 2012); thus most certainly the number new species of Liolaemus will continue to increase (Lobo et al. 2010). A similar situation occurs with the sister genus Phymaturus, for which morphological (Lobo et al. 2012d) and molecular studies (Morando et al. 2012) have suggested a total of 31 new candidate species. Other genera like Diplolaemus and Homonota are being intensively studied, and preliminary data indicate that they harbor unknown diversity at the species level (Morando et al., unpublished). Furthermore, to our knowledge, at least 20 new species of Argentinean lizards are currently being described by various authors. This scenario implies that this checklist is going to continue to be dynamic in the near future.

\section{Introduced (non-native) species}

Although we are not including introduced species in our checklist, we want to highlight the point that two species of lizards have been introduced and are now established in Argentina. Hemidactylus mabouia is known from Buenos Aires (Williams 1988), Chaco (Federico \& Cacivio 2000), Corrientes (Álvarez et al. 2002) and Misiones (Genise \& Montanelli 1991; Baldo et al. 2008) provinces, and Tarentola mauritanica from Ciudad Autónoma de Buenos Aires, Buenos Aires (Williams 1988) and Tucumán province (Cabrera \& Guerra 2006). The impact of these introductions is unknown, but apparently until now, introduced species are restricted to urbanized zones.

\section{Comments about some species status and their presence in Argentina}

\section{Amphisbaena angustifrons Cope, 1861}

This species was included as Amphisbaena angustifrons angustifrons in Avila et al. (2000) and elevated to full species status by Gans (2005) without any explicit study.

\section{Amphisbaena plumbea Gray, 1872}

This species was included as Amphisbaena angustifrons plumbea in Avila et al. (2000) and elevated to full species status by Gans (2005) without any explicit study.

\section{Amphisbaena heterozonata Burmeister, 1861}

This species was included as Amphisbaena darwinii spp. by Avila et al. (2000) and as Amphisbaena darwinii heterozonata by Montero (1996); a few years later Gans (2005) considered it a full species as Amphisbaena heterozonata without any justification. Identification of individuals of some regions is difficult (Montero 1996), and using their geographic distributions alone is not accurate enough to make taxonomic decisions; thus we do not include these species by province in our checklist. Probably, Argentinean amphisbaenians need more detailed studies incorporating new methodological (and theoretical) approaches to quantify species limits and phylogenetic relationships.

\section{Anisolepis undulatus (Wiegmann, 1834).}

Anisolepis undulatus was first cited as A. bruchi from Punta Lara, on the south bank of the Rio de La Plata in northeastern Buenos Aires Province (Koslowsky 1895). Since then, no specimens have been collected again in Argentina (Etheridge \& Williams 1991). This species, as others in this group, is very difficult to find (arboreal habits, cryptic coloration and inconspicuous behavior) and its presence can remain unnoticed, even for a skilled herpetologist. Some areas, including poorly surveyed regions along the Parana and Uruguay rivers, could maintain some remnant populations of this species, because they have similar habitats in Uruguay. But since more than hundred years has passed since its citation, we prefer to delete this species from the checklist. 


\section{Cercolophia borelli (Peracca, 1897)}

The presence of this species for Argentina in based on two specimens (see Montero 1996). We maintain its presence in Argentina given that the specimens cited from Argentina apparently were competently identified (Montero 1996), and taking into consideration the difficulty of finding amphisbaenas in the field.

\section{Cercosaura ocellata (Ruibal, 1952).}

Presence of this species for Argentina is based on the collection of one specimen in northern Corrientes Province (Tedesco \& Aguirre 1998). The specimen was collected near the coast of Parana River and could have been transported from northern Parana River Basin; thus more specimens should be collected to confirm the presence of this species in Argentina.

\section{Cercosaura steyeri (Tedesco, 1998).}

This species was described based on only one specimen, so more studies are to evaluate the taxonomic (= distributional) status of this species.

\section{Homonota darwinii macrocephala (Cei, 1978b).}

Described for a locality in the northernmost area of Argentina (Cei 1978), very far away from Patagonia, the current geographic distribution of Homonota darwinii; thus the taxonomic status of this subspecies must be reviewed.

\section{Liolaemus anomalus Koslowsky, 1896.}

Described for La Rioja province, this species has not been found again in this province. It is a species very difficult to find, with cryptic coloration and particular behavior, and probably very low population density. In 1983 , Cei described a subspecies, Liolaemus anomalus ditadai, which was recently elevated to the status of species by Abdala (2007a), and extended its geographic range to the southeastern corner of Santiago del Estero Province. As a result of this last nomenclatural arrangement, the distribution of $L$. anomalus must be restricted to desert lowlands of southern San Juan and northern Mendoza Provinces, and its presence in La Rioja is doubtful. A recent thesis by Juarez Heredia (2011) review the status of the Liolaemus anomalus group and proposed several new species.

\section{Liolaemus araucaniensis Müller \& Hellmich, 1932}

The presence of this species in Argentina was cited by Scolaro (2006) but without mention of any voucher specimen and no specimens were available in any of the reviewed collections. Scolaro (personal communication) confirmed the existence of one specimen from western Neuquén in his personal collection and others from Batea Mahuida Volcano in Chilean collections. For that reason we included this species in the Argentinean herpetofauna. A photograph of a specimen collected in western Neuquen is given in Figure 2 (J.A. Scolaro herpetological collection). Recently, we found some samples identified as Liolaemus araucaniensis in the LJAMM-CNP collection from Malleo River, in northern Lanin National Park (LJAMM-CNP 907-913).

\section{Liolaemus chacabucoense Nuñez \& Scolaro, 2009}

This species was recently described from a Chilean locality very close to the Argentinean border (Nuñez \& Scolaro, 2009) and was cited for Argentina by Breitman et al. (2011); some populations of the Argentina-Chile border could be related to this species but a more comprehensive study is in preparation (Breitman et al. unpublished data).

\section{Liolaemus chillanensis Müller \& Hellmich, 1932}

We have evidence of the presence of this species in Argentina based only on photographic records taken in northwestern Neuquén province (Figure 2). Presence must be confirmed with vouchered specimens to maintain the presence of this species in Argentina. Liolaemus species of the monticola group are probably present in the high mountains of Neuquén Province, but until the conclusion of a revisionary study of this group, we are not including any species in our checklist (Medina, PhD thesis in progress). 


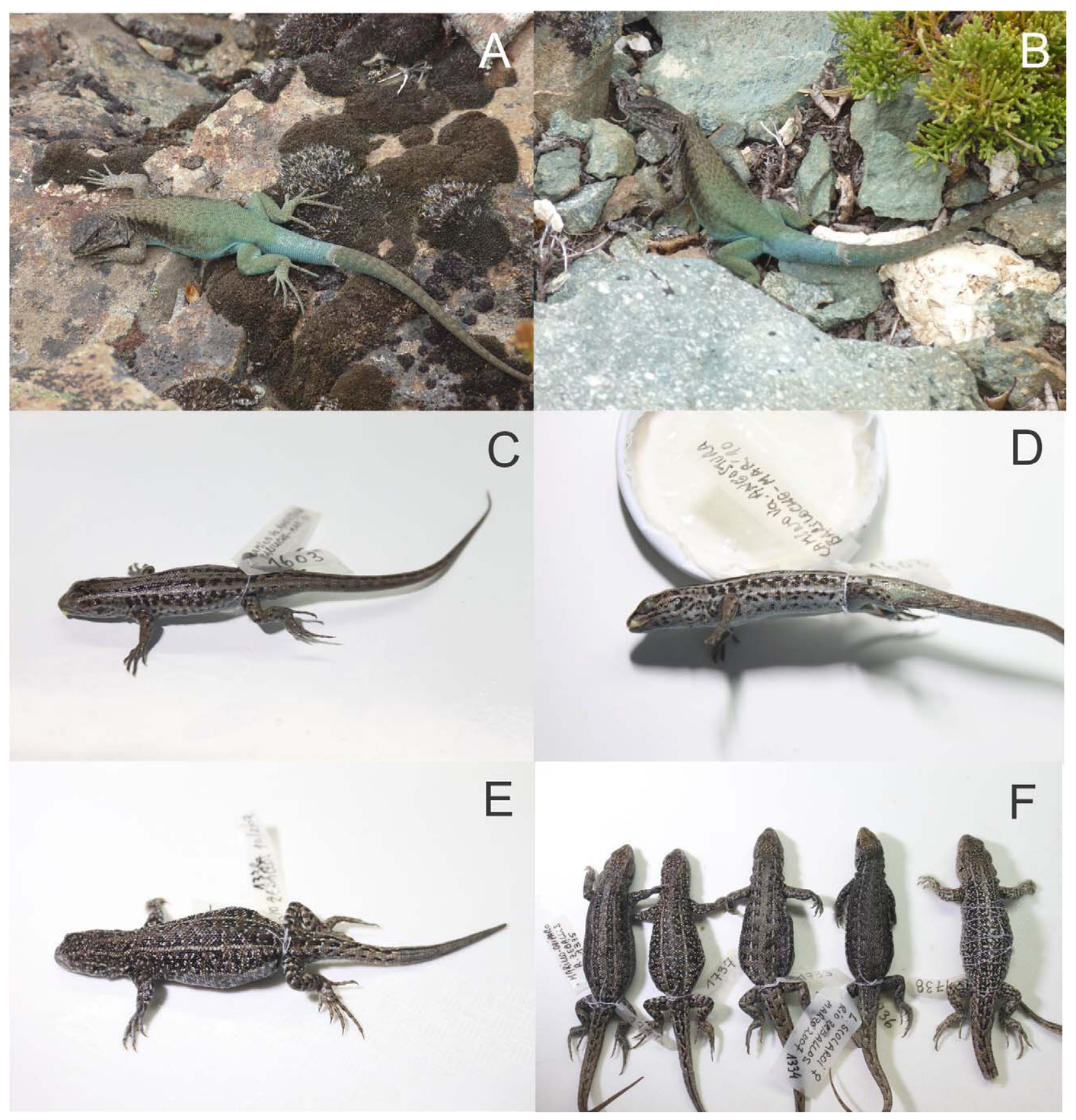

FIGURE 2. Some species with marginal distribution in Argentina. A/B: Liolaemus chillanensis from upper mountains of western Neuquén; C/D: Liolaemus araucaniensis from "Camino a La Angostura, Bariloche, Neuquén”; E/F: Liolaemus scolaroi from Río Ceballos valley, northwestern Santa Cruz Province, Argentina.

\section{Liolaemus chlorostictus Laurent, 1991.}

Previously included in Avila et al. (2000) as Liolaemus orientalis chlorostictus, this was considered as a valid full species without any explanation by Díaz Gómez (2007).

\section{Liolaemus exploratorum Cei \& Williams, 1984.}

Described from museum material only, this species was never found in the wild (Cei \& Williams 1984, Fig. 1). A recent summary about this species was made by Williams (2003) and Ferraro and Williams (2006), and we maintain it for the Argentinean herpetofauna until more surveys on its broad type locality can confirm its status. Liolaemus exploratorum is a morphologically similar to some populations of Liolaemus bibronii, a complex of several still undescribed species (Martínez 2012), and in the type locality region we only collected specimens of the nominal species. 
Liolaemus constanzae Donoso-Barros, 1961 was cited by Cei (1993) for Socompa, Salta Province, in northwestern Argentina, but we were unable to find any reliable bibliographic citation or reference material collected in argentinean territory.

Liolaemus gravenhorsti (Gray, 1845) was cited from Mendoza province in 1974 by Cei and Roig (1974) based on two specimens collected at Valle Hermoso, Malargüe Department. But according to Cei and Videla (2001) only one specimen remains in collection. In a recent review of Liolaemus in the Museum of Vertebrate Zoology, Univ. California-Berkeley, we found two additional specimens (MVZ 247047/8) from the same locality that could be refereable to L. gravenhorsti. Cei and Videla (2001) cited the species for San Juan province, using two lizards (a male and a juvenile) collected by botanists in 1990. Collection locality is in the "altiplanicies de Calingasta, cerca

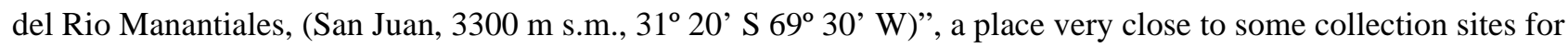
L. fitzgeraldi (Avila 2004), and Cei and Videla (2001) mention some differences with the samples from Mendoza. The altitude mentioned by Cei and Videla is not consistent with the elevation found using Google Earth for those geographic coordinates. Until more conclusive evidence is available about the identity of these specimens from San Juan, we maintain the distribution of $L$. gravenhorsti for both provinces.

\section{Liolaemus hermannunezi Pincheira-Donoso, Scolaro \& Schulte, 2007.}

Described by Pincheira-Donoso et al. (2007) for Chile, this species was cited by Abdala \& Quinteros (2007) for the Argentinean territory, but this population was recently described as Liolaemus tromen by Abdala et al. (2012a). We keep this species as part of the Argentinean herpetofauna because the typical habitat where the species is found in Chile extends to some areas of Neuquén province, and some still unstudied populations found in Minas and Chos Malal departments can be considered as L. hermannunezi (voucher specimens are deposited in LJAMMCNP collection).

\section{Liolaemus lemniscatus (Gravenhorst, 1838)}

This species was recently excluded by Quinteros (2012) from Argentina. This author suggests that with the recognition of Liolaemus abdalai, all populations of L. lemniscatus will be restricted to localities of central Chile. However until more evidence is found, we prefer to maintain the inclusion of this species in Argentina.

\section{Liolaemus lentus Gallardo, 1964}

This species was originally described by Gallardo (1966) for Altos de Cochico, western La Pampa Province. It was synonymized with Phrynosaura werneri by Donoso Barros (1969), and ten years later, Cei (1979) synonymized $P$. werneri with $L$. anomalus (and therefore $L$. lentus with $L$. anomalus), Recently $L$. lentus was elevated to species status by Abdala (2007a); it is poorly known and has characteristics and behavior similar to Liolaemus anomalus. It is distributed in La Pampa and San Luis provinces (Abdala 2007a, Pérez \& Avila 2011).

\section{Liolaemus pictus argentinus Müller \& Hellmich, 1939.}

Two subspecies were cited in the literature for the Argentinean territory, L. pictus pictus and L. pictus argentinus (Cei \& Williams 1984), but only the last one is probably present (see Avila et al. 2006c for a small review). More field surveys are needed to confirm the presence of L. pictus pictus in Argentina and the distribution of southern populations. In fact, the presence of Liolaemus pictus pictus is based on old material collected in a locality without the typical habitat for the species (Cei \& Williams 1984), and the presence of this species as far as Santa Cruz Province has not yet been confirmed.

\section{Liolaemus puritamensis Nuñez \& Fox, 1989}

Cited for Argentina by Quinteros and Abdala (2007) from Jujuy province, but the taxonomic status of this species remains unclear. It was described by Nuñez and Fox (1989), synonymized with $L$. dorbignyi by Nuñez and Jaksic (1992), and revalidated again by Pincheira-Donoso and Nuñez (2005).

\section{Liolaemus rabinoi (Cei, 1974)}

This species was for a long time considered as extinct because it has not been collected since its original description by Cei (1974); however, this species was recently found in a dune area near the type locality (Abdala, pers. comm.). 


\section{Liolaemus scolaroi Pincheira-Donoso \& Nuñez, 2005}

The presence of this species in Argentina was cited by Scolaro (2006), but without mention of any voucher specimen and no specimen was available in any of the reviewed collections. Scolaro confirmed that several specimens collected from Rio Ceballos (Santa Cruz province), near the type locality, are deposited in his personal collection (Scolaro, personal communication; see Fig. 2). For that reason we included the species in the Argentinean herpetofauna.

\section{Phymaturus agilis Scolaro, Ibargüengoytía \& Pincheira-Donoso, 2008.}

Recently this species was considered as a synonym of Phymaturus spectabilis, based on the finding of sympatric and apparently interbreeding individuals (Lobo et al. 2012a). This was taken as evidence of a lack of reproductive isolation between "the $P$. «agilis» morph and $P$. spectabilis", as well as the lack of significant differences in meristic and morphometrics characters between these "morphs". Its taxonomic status must be evaluated with further studies using different lines of evidence.

\section{Ophiodes fragilis Peters, 1877}

Argentinean populations of this species were named as Ophiodes yacupoi Gallardo, 1966 for a long time, but new evidence (Martins 1998) suggests that this species must be named as $O$. fragilis.

\section{Phymaturus desuetus Scolaro \& Tappari, 2009.}

This species was described based on one individual from a region with an apparently relatively high number of species of Phymaturus, but current data are insufficient to verify species boundaries vs the presence of one geographically structured species with extensive polymorphisms. Its taxonomic status must be evaluated with further studies.

\section{Phymaturus dorsimaculatus Lobo \& Quinteros, 2005.}

This species was described based on a single female, and was considered as a synonym of Phymaturus vociferator by Pincheira-Donoso et al. (2008), mainly because this population is close to the type locality of $P$. dorsimaculatus in a very similar environment. No intermediate populations were found during our field work along the area that separates both localities, and its taxonomic status must be evaluated with further studies.

\section{Phymaturus gynechlomus Corbalán, Scolaro, \& Debandi, 2009}

Lobo et al. (2010b) suggested that this species is a junior synonym of Phymaturus palluma, but a detailed study is still absent, thus further studies must be done to confirm its taxonomic status.

\section{Phymaturus palluma (Bell, 1843).}

Scolaro (2010) recently redescribed the neotype of Phymaturus palluma, suggesting the "UspallataParamillos" site as type locality and rejected the proposed synonym of P. gynechlomus with P. palluma by Lobo et al. (2010a).

\section{Stenocercus azureus (Müller, 1880).}

The presence of this species in Argentina is poorly documented. According to Cei (1986) it was cited by Koslowsky for Misiones Province, but we lack any reliable information about its presence in Argentinean territory. Since the typical habitat of this species in Uruguay and Brazil is found in adjacent areas in Argentina, it is very probable than in the future we can include it again in the Argentinean herpetofauna, but its presence must be confirmed with voucher specimens. In the last revision of the genus by Torres-Carvajal (2007), he did not mention the species for Argentina and all reviewed localities are distant from the Argentinean border.

Tropidurus torquatus (Wied-Neuwied, 1820). A recent field guide did not include the species in Misiones province (Lopez \& Prado 2012).

The taxonomic status of the Argentinean populations currently allocated to Tropidurus torquatus is still to be studied, but we maintain the name Tropidurus torquatus catalanensis to avoid more nomenclatural confusions, despite the suggestion of Cei (1993) to recognize the Argentinian populations as Tropidurus torquatus. As the type locality of Tropidurus torquatus is in the eastern region of Brazil (Trefaut Rodriguez 1987), it is probable that the Argentinean populations could be a different species. 


\section{Discusion and conclusions}

Squamates are the most speciose clade of reptiles. They comprise more than 9,187 species, and excluding snakes, there are approximately 5,634 species of lizards and 181 amphisbaenians; which leave these groups with the greatest number of extant species among living reptile groups (Uetz 2012, Vitt \& Caldwell, 2009). Lizard fauna of Argentina includes 261 species, 92 more than our previous list of Avila et al. (2000), but this number will be increased in the next few months because several descriptions of new species of Liolaemus, Homonota, and Phymaturus are being published. This number is relatively high in comparison with other countries of South America like Brazil, which is a megadiverse country, with a number of lizards plus amphisbaenians of 315 in late 2011 (Sociedade Brasileira de Herpetologia, 2012) and represent almost $5.59 \%$ of global diversity. Following this comparison, there are 261 species of lizard species in Argentina and 248 in Brazil, a striking result for a country three times smaller in geographic extension. This could be an artifact of our present knowledge, since the species diversity of Brazil is still high, but it seems that the tendency in Argentina will follow that of previous years, and more species are being discovered with more intense field sampling and detailed systematic studies. On the other side, some species have been suggested as synonyms of other species, like Phymaturus agilis, P. gynechlomus, and P. dorsimaculatus (Pincheira-Donoso et al. 2008, Lobo et al. 2010a, Lobo et al. 2012a), and probably some species of Liolaemus can also be synonimized. The high number of lizard's species in Argentina is mainly attributed to the high number of species of the Liolaemus and Phymaturus genera. Intensive field trips were carried out in the last 10 years and a significant number of new species were discovered and described. In contrast, other genera are still poorly studied and relatively poorly known, like Ophiodes, Aspronema, Notomabuya, Tropidurus, Cnemidophorus, Kentropyx, all genera belong to Gymnophthalmidae family, or some species of Leiosaurae. Some of the reasons for this situation could be attributed to the marginal distribution of some species, but in other cases the causes are more complex, from general lack of support for basic taxonomy studies, abscense of adequate support for field or museum studies, persistence of old research methodology and difficulties associated to adopt new analitical techniques, little interest in less diversed or marginal groups, etc. This tendecy seems to be under change for some cases with the support of some related areas (e.g. the iBOL-Argentina fund, National System of Biological DataSNDB), but a clear support policy towards the formation of skilly taxonomists and support their jobs is still, in general, absent. Some species of these groups are distributed in regions that are suffering heavy environmental modifications as a result of the extension of crops, mainly soy. Huge areas of Chaco, Córdoba, Formosa, La Pampa, Santa Fe Santiago del Estero, and Salta were completely deforested in the last years, the tendency is not changing, and with very small exceptions, nobody knows the lizard diversity of those areas. In the majority of those provinces, only preliminary, old or incomplete reports on lizards were made. Some data from these regions were based on material collected in late XIX or early XX centuries, species identifications were erroneous, material is not available anymore, or localities were wrong, leaving the lizard fauna knowledge of some places unknown. Some recent studies show that the lizard diversity of Argentina is expected to increase at least in some genera, especially in Liolaemus and Phymaturus, probably at the same level as during the last 10 years (e.g. Morando et al. 2003, Avila et al. 2006b, Abdala et al. 2007, Breitman et al. 2011c).

As we stated before, checklists are dynamic and change with time. We think that an updated general checklist of argentinean lizards was necesary at this time. They are useful for systematic and taxonomic, ecological or basic studies of the biology of the species, but above all they serve as a basic framework for conservation, biogeography or general management of the fauna.

\section{Acknowledgments}

We thank our colleagues A. Camargo, F. Breitman, P. Escudero, N. Feltrin, N. Frutos, M. Hawkins, M. Kozykariski, R. Martinez, C. Medina, I. Minoli, M. Nicola, R. Otteson, C.H.F. Pérez, D.R. Perez, M. Olave, C. Zanotti, and other people of the Grupo de Herpetología Patagónica of CENPAT, for help in the revision of earlier version of this manuscript, field and lab work, or/and helpful suggestions. Photograph of Liolaemus chillanensis were kindly provided by S. Di Martino APN-Neuquén. We thank Fauna authorities of provinces of Catamarca, Neuquen, Chubut, La Pampa, Mendoza, Rio Negro and Santa Cruz, as well as Administracion de Parques Nacionales for collection permits. We thank S. DiMartino, M. Aubone, M. Funes, M. Monteverde, S. Goitia, and F. 
Quiles for support our field activities. We thank J.A. Scolaro (CENPAT) for sharing information about Liolaemus araucaniensis and L. scolaroi and allowing us to see and photograph samples of both species. We thank curators, technicians and researchers in charge or working in the collections cited in Material and Methods section, who kindly helped us during our visits including: J.C. Acosta, B. Alvarez, A. Brigada, A. Guerreiro, G.R. Carrizo, C. Cicero, J.M. Gallardo, R. Heyer, J.F. Jacobs, S. Kretschmar, O. Lagiglia, R. Martori, J. McGuire, A. Resetar, V. Roig, J. Rosado, G. Scrocchi, C. Spencer, S. Tiranti, F. Videla, J. Virasoro, J.D. Williams. ANPCYT, Brigham Young University, CONICET, Gobierno de la Provincia del Chubut, National Geographic Society and National Science Foundation provided funds for field trips and collection visits. NSF-PIRE award (OISE 0530267) for support of collaborative research on Patagonian Biodiversity granted to the following institutions (listed alphabetically): Brigham Young University (BYU), Centro Nacional Patagónico (AR), Dalhousie University, Instituto Botánico Darwinion (AR), Universidad Austral de Chile, Universidad de Concepción, Universidad Nacional del Comahue, Universidad Nacional de Córdoba, and University of Nebraska. We thank K. Crandall and others members of Brigham Young University for support our research at BYU. We specially thank J.W. Sites, Jr. of BYU for its support, friendship and encouragement along this years; he provides financial support and information that allow us to visit collections or receive museum material and to carry out field works that make possible this checklist.

\section{Literatura cited}

Abdala, C.S. (2002) Nuevo Liolaemus (Iguania: Liolaemidae) perteneciente al grupo boulengeri de la provincia de Neuquén, Argentina. Cuadernos de Herpetología, 16, 3-14.

Abdala, C.S. (2003) Cuatro nuevas especies del género Liolaemus (Iguania: Liolaemidae), pertenecientes al grupo boulengeri, de la Patagonia, Argentina. Cuadernos de Herpetología, 17, 3-32.

Abdala, C.S. (2005a) Dos nuevas especies del género Liolaemus (Iguania: Liolaemidae) y redescripción de Liolaemus boulengeri (Koslowsky, 1898). Cuadernos de Herpetología, 19, 3-34.

Abdala, C.S. (2005b) Una nueva especie del género Liolaemus perteneciente al complejo darwinii (Iguania: Liolaemidae) de la provincia de Catamarca, Argentina. Revista Española de Herpetología, 19, 5-17.

Abdala, C.S. (2007a). Phylogeny of the boulengeri group (Iguania, Liolaemidae, Liolaemus) based on morphological and molecular characters. Zootaxa, 1538, 1-84.

Abdala, C.S. (2007b) Estatus de Liolaemus ditadai, Cei 1983, (Iguania: Liolaemidae) y ampliación de su rango de distribución. Cuadernos de Herpetología, 21, 59-63.

Abdala, C.S. \& Díaz Gómez, J.M. (2001) Novedad Zoogeográfica: Liolaemus silvanae (Donoso Barros \& Cei, 1971) (Iguania: Liolaemidae). Cuadernos de Herpetología, 15, 143-144.

Abdala, C.S. \& Díaz Gómez, J.M. (2006) A new species of the Liolaemus darwinii group (Iguania: Liolaemidae) from Catamarca Province, Argentina. Zootaxa, 1317, 21-33.

Abdala, C.S. \& Juarez, R. (2006) Geographic distribution. Liolaemus donosobarrosi. Herpetological Review, 37, 106.

Abdala, C.S. \& Lobo, F. (2006a) Geographic distribution. Liolaemus loboi. Herpetological Review, 37, 197.

Abdala, C.S. \& Lobo, F. (2006b) Description of a new patagonian lizard species of de Liolaemus silvanae group (Iguania: Liolaemidae). South American Journal of Herpetology, 1, 1-8. http://dx.doi.org/10.2994/18089798(2006)1[1:DOANPL]2.0.CO;2

Abdala, C.S. \& Lobo, F. (2006c) Nueva especie del grupo de Liolaemus darwinii (Iguania: Liolaemidae) del noroeste de Argentina. Cuadernos de Herpetología, 19, 3-18.

Abdala, C.S \& Juarez, R. (2007) Geographic distribution: Phymaturus verdugo. Herpetological Review, 38, 101-102.

Abdala, C.S. \& Quinteros, S. (2007) Liolaemus hermannunezi Pincheira-Donoso et al., 2007 (Iguania, Liolaemidae). Cuadernos de Herpetología, 21, 119.

Abdala, C.S. \& Robles, C. (2007) Geographic distribution: Liolaemus buergeri. Herpetological Review, 38, 101.

Abdala, C.S. \& Lobo, F. (2007) Geographic distribution: Liolaemus umbrifer. Herpetological Review, 38, 101.

Abdala, C.S., Martinez, F. \& Muñoz, L. (2007) Geographic distribution: Liolaemus laurenti. Herpetological Review, $38,353$.

Abdala, C.S. \& Quinteros, S. (2008) Una nueva especie de Liolaemus (Iguania: Liolameidae) endémica de la Sierra de Fiambalá, Catamarca, Argentina. Cuadernos de Herpetología, 22, 35-47.

Abdala, C.S., Quinteros, S. \& Espinosa, R.E. (2008) Two new species of Liolaemus (Iguania: Liolaemidae) from Puna of northwestern Argentina. Herpetologica, 64, 458-471. http://dx.doi.org/10.1655/08-022R1.1

Abdala, C.S., Acosta, J.C., Cabrera, M.R., Villavicencio, H.J. \& Marinero J. (2009) A new andean Liolaemus of the L. montanus series (Squamata: Iguania: Liolaemidae) from western Argentina. South American Journal of Herpetology, 4 , 91-102. http://dx.doi.org/10.2994/057.004.0201

Abdala, C.S., Quinteros, A.S., Scrocchi, G.J. \& Stazzonelli, J.C. (2010) Three new species of the Liolaemus elongatus group (Iguania: Liolaemidae) from Argentina. Cuadernos de Herpetología, 24, 93-109. 
Abdala, C.S., Quinteros, A.S., Arias, F. Portelli, S. \& Palavecino, A.P. (2011) A new species of the Liolaemus darwinii group (Iguania: Liolaemidae) from Salta Province, Argentina. Zootaxa, 2968, 26-38.

Abdala, C.S., Semhan, R.V., Moreno Azocar, D.L., Bonino, M., M. Paz M. \& Cruz, F. (2012a) Taxonomic study and morphology based phylogeny of the patagonic clade Liolaemus melanops group (Iguania: Liolaemidae), with the description of three new taxa. Zootaxa, 3163, 1-32.

Abdala, C.S., Díaz Gómez, J.M. \& Heredia, V.I.J. (2012b) From the far reaches of Patagonia: New phylogenetic analyses and description of two new species of the Liolaemus fitzingerii clade (Iguania: Liolaemidae). Zootaxa, 3301, 34-60.

Acosta, J.C. \& Gomez, P. (2000) Geographic distribution. Tupinambis rufescens. Herpetological Review, $31,185$.

Acosta, J.C. \& Murúa, F. (2000) Geographic distribution. Liolaemus riojanus. Herpetological Review, $31,53$.

Acosta, J.C., Ortíz, G. \& Murúa, F. (2000) Geographic distribution. Liolaemus fitzgeraldi. Herpetological Review, $31,185$.

Acosta, J.C. \& Blanco, G. (2001) Geographic distribution. Homonota andicola. Herpetological Review, 32, 120.

Acosta, J.C. Villavicencio, H.J., \& Marinero, J.A. (2007) Anfibios y Reptiles. Biodiversidad, bio-ecologia y especies de valor especial para monitoreo. In: Martinez Carretero, E. (Ed.). Diversidad biológica y cultural de los altos Andes centrales de Argentina. Universidad Nacional de San Juan, Argentina. 284 pp.

Aguirre, R.H. \& Cespedez, J.A. (2001) Geographic distribution. Vanzosaura rubricauda. Herpetological Review, $32,121$.

Alvarez, B.B. (2000) Geographic distribution. Anisolepis grilli. Herpetological Review, 31, 253.

Alvarez, B.B., Aguirre, R.H., Céspedez, J. A., Hernando, A. \& Tedesco, M. E. (2002) Atlas de anfibios y reptiles. Facultad de Ciencias Exactas y Naturales y Agrimensura, $160 \mathrm{pp}$.

Alvarez, B.A., Ruiz Garcia, J.A., Cespedez, J.A., Hernando, A.B., Zaracho, V.H., Calamante, C.C., \& Aguirre, R.H. (2009) Herpetofauna, provinces of Chaco and Formosa, Chaco Oriental region, north-eastern Argentina. Check List, 5, 74-82.

Arias, F. \& Lobo, F. (2005) Geographic distribution. Cnemidophorus serranus. Herpetological Review, $36,467$.

Avila, L.J. (2003) A new species of Liolaemus (Squamata: Liolaemidae) from northeastern Argentina and southern Paraguay. Herpetologica, 59, 282-291. http://dx.doi.org/10.1655/02-67

Avila, L.J. 2004. On the geographic distribution of the Andean liolaemid lizard Liolaemus fitzgeraldi (Squamata, Liolaemidae). Bulletin of Chicago Herpetological Society, 39, 8-9.

Avila, L.J., Montero, R. \& Morando, M. (2000) Evaluación del estado de conservación de la fauna de lagartijas y anfisbénidos de la República Argentina. In: Lavilla, E.O., Richard, E.R., y Scrocchi, G.J. (Eds.) Categorización de Anfibios y Reptiles de Argentina. Asociación Herpetológica Argentina, 108 pp.

Avila, L.J., Morando, M. \& Pérez, C.H.F. (2001) New records and natural history notes for lizards and snakes from Patagonia, Argentina. Herpetological Review, 32, 64-65.

Avila, L.J., Pérez, C.H.F., Morando, M. \& Frutos, N (2002) New records for Liolaemus grosseorum Etheridge, 2001 (Reptilia: Squamata: Liolaemidae) from northwestern Patagonia. Bulletin of the Chicago Herpetological Society, 37, 100-101.

Avila, L.J. \& Carrizo, G.R. (2003) Lista comentada y distribución geográfica de la herpetofauna de la provincia de San Luis Argentina. Acta Zoológica Lilloana, 47, 93-116.

Avila, L.J., Morando, M. \& Belver, L.C. (2003a) Natural history and geographic distribution of the desert lizard Liolaemus pseudoanomalus (Squamata: Iguania: Liolaemidae) from northern Monte region, Argentina. Bulletin of the Chicago Herpetological Society, 38, 52-53.

Avila, L.J., Morando, M. \& Pérez, C.H.F. (2003b) New records and natural history notes for Pristidactylus nigroiugulus Cei, Scolaro \& Videla, 2001 from Río Negro and Chubut provinces, Argentina. Herpetozoa, 16, 83-86.

Avila, L.J., Perez, C.H.F. \& Morando M. (2003c) A new species of Liolaemus (Squamata: Iguania: Liolaemidae from northwestern Patagonia (Neuquén, Argentina). Herpetologica, 59, 534-545. http://dx.doi.org/10.1655/02-67

Avila, L.J., Morando, M., Pérez, C.H.F. \& Sites Jr., J.W. (2004a) New records and natural history notes of lizards of the genus Liolaemus in northern Patagonia. Herpetozoa, 17, 83-86.

Avila, L.J., M. Morando, M., Pérez, C.H.F. \& Sites Jr., J.W. (2004b) Phylogenetic relationships of lizards of the Liolaemus petrophilus group (Squamata, Liolaemidae), with description of two new species from western Argentina. Herpetologica, 60, 187-203. http://dx.doi.org/10.1655/03-04

Avila, L.J. \& Pérez, D.R. (2006) Notes on geographic distribution. Liolaemus punmahuida. Check List, 2, 55-56.

Avila, L.J., Martinez, L.E. \& Morando, M. (2006a) Lista actualizada y comentada de los saurios de Argentina. Resumenes VII Congreso Argentino de Herpetologia. Corrientes, Argentina. pp. 89

Avila, L.J., Morando, M. \& Sites Jr., J.W. (2006b) Congeneric phylogeography: hypothesizing species limits and evolutionary processes in Patagonian lizards of the Liolaemus boulengeri group (Squamata: Liolaemini). Biological Journal of the Linnean Society, 89, 241-275. http://dx.doi.org/10.1111/j.1095-8312.2006.00666.x

Avila, L.J., Frutos, N., Pérez, C.H.F., Kozykariski, M. \& Morando, M. (2006c) Reptilia, Iguania, Liolaemini, Liolaemus petrophilus and Liolaemus pictus: geographic distribution, filling gaps, new records. Check List, 2, 65-69.

Avila, L.J., Frutos, N., \& Morando, M. (2006d) New records of Liolaemus inacayali Abdala, 2003 in western Río Negro province, Patagonia, Argentina. Herpetozoa, 19, 3-4.

Avila L.J, Kozykariski, M., Feltrin, N \& Morando, M. (2007a) Geographic distribution: Amphisbaena plumbea. Herpetological Review, 38, 217.

Avila, L.J., Pérez, C.H.F., Morando, M. \& Sites Jr, J.W. (2007b) Geographic distribution: Liolaemus fitzingerii. Herpetological Review, 38, 352.

Avila, L.J., Frutos, N., Pérez, C.H.F., Pérez, D.R. \& Morando, M. (2007c) Reptilia, Iguania, Liolaemidae, Liolaemus 
somuncurae: Distribution extension. Check List, 3, 11-13.

Avila, L.J., Pérez, C.H.F., Pérez, D.R. \& Morando, M. (2007d) Reptilia, Squamata, Liolaemidae, Phymaturus verdugo: Distribución extension, new provincial records, filling gaps, and geographic distribution map. Check List, 3, 250-252.

Avila, L.J., Morando, M., Pérez, C.H.F. \& Sites Jr., J.W. (2007e) A new species of Liolaemus (Reptilia: Squamata: Liolaemini) from southern Mendoza province, Argentina. Zootaxa, 1452, 43-54.

Avila, L.J., Morando, M. \& Sites Jr., J.W. (2008) New species of the iguanian lizard genus Liolaemus (Squamata, Iguania, Liolaemini) from central Patagonia, Argentina. Journal of Herpetology, 42, 186-196. http://dx.doi.org/10.1670/06244R2.1

Avila, L.J., Morando, M., Pérez, D.R. \& Sites Jr., J.W. (2009) A new species of Liolaemus from Añelo sand dunes, northern Patagonia, Neuquén, Argentina, and molecular phylogenetic relationships of the Liolaemus wiegmannii species group (Squamata, Iguania, Liolaemini). Zootaxa, 2234, 39-55.

Avila, L.J., Morando, M., Pérez, C.H.F. \& Sites Jr., J.W. (2010a) A new species of Liolaemus (Reptilia: Squamata) from southwestern Rio Negro province, northern Patagonia, Argentina. Zootaxa, 2434, 47-59.

Avila, L.J., Morando, M., Pérez, D.R. \& Sites Jr., J.W. (2010b) A new species of the Liolaemus elongatus group (Squamata: Iguania: Liolaemini) from Cordillera del Viento, northwestern Patagonia, Neuquén, Argentina. Zootaxa, 2667, $28-42$.

Avila, L.J., Martinez, L.E. \& Morando, M. (2011a) Lista de las lagartijas y anfisbaenas de Argentina: una actualización. Los que se van, Buenos Aires, pp. 26. Available from: http://www.losquesevan.com> (December 2011).

Avila, L.J., Pérez, C.H.F. Pérez, D.R. \& Morando M. (2011b) Two new mountain lizard species of the Phymaturus genus (Squamata: Iguania) from northwestern Patagonia, Argentina. Zootaxa, 2924, 1-21.

Avila, L.J., Pérez, C.H.F. Medina, C.D., Sites Jr., J.W. \& Morando M. (2012a) A new species of lizard of the Liolaemus elongatus clade (Reptilia: Iguania: Liolaemini) from Curi Leuvu River Valley, northern Patagonia, Neuquén, Argentina. Zootaxa, 3325, 37-52.

Avila, L.J., Pérez, C.H.F., Minoli, I. \& Morando, M. (2012b) A new species of Homonota Gray, 1845 (Reptilia: Squamata: Gekkota: Phyllodactylidae) from the Ventania mountain range, Southeastern Pampas, Buenos Aires Province, Argentina. Zootaxa, 3431, 19-36.

Avila, L.J., Olave, M.,Pérez, C.H.F., Perez, D.R. \& Morando, M. (2012c) Molecular phylogenetic relationships of the Liolaemus rothi complex and a new species of lizard from Auca Mahuida Volcano (Squamata: Liolaemini). Zootaxa 3608(4), 221-238.

Baldo, D., Borteiro, C., Brusquetti, F., García, J. E. \& Prigioni, C. (2008) Reptilia, Gekkonidae, Hemidactylus mabouia, Tarentola mauritanica: Distribution extension and anthropogenic dispersal. Check List, 4, 434-438.

Breitman, M.F., Avila, L.J. , Sites Jr., J.W. \& Morando, M. (2011a) Lizards from the end of the world: phylogenetic relationships of the Liolaemus lineomaculatus section (Squamata: Iguania: Liolaemini). Molecular Phylogenetics and Evolution, 59, 365-376. http://dx.doi.org/10.1016/j.ympev.2011.02.008

Breitman, M.F., Parra, M., Pérez, C.H.F. \& Sites Jr., J.W. (2011b) New species of lizard from the magellanicus clade of the Liolaemus lineomaculatus section (Squamata: Iguania: Liolaemidae) from southern Patagonia. Zootaxa, 3120, 1-28.

Breitman, M.F., Pérez, C.H.F., Parra, M., Morando, M., Sites Jr., J.W. \& Avila, L.J. (2011c) New species of lizard from the magellanicus clade of the Liolaemus lineomaculatus section (Squamata: Iguania: Liolaemidae) from southern Patagonia. Zootaxa, 3123, 32-48.

Breitman, M.F., Avila L.J., Sites, Jr., J.W. \& Morando, M. (2012) How lizards survived blizzards: phylogeography of the Liolaemus lineomaculatus group (Liolaemidae) reveals multiple breaks and refugia in southern Patagonia, and their concordance with other co-distributed taxa. Molecular Ecology, 21, 6068-6085. http://dx.doi.org/10.1111/mec.12075

Briguera, V., Tamburini, D., Kufner, M., Gavier, G., Giraudo, L., Torres, R. \& Bechara, V. (2005) Herpetofauna en relictos de bosque chaqueño de la región de Mar Chiquita, Córdoba. Cuadernos de Herpetologia, 20, 25-31.

Buff, R., Gomez, P., Marinero, J. \& Villavicencio, J. (2001) Geographic distribution. Liolaemus uspallatensis. Herpetological Review, 32, 193.

Cabrera, M.R. (2002) New records for Ameiva ameiva (L., 1758) (Squamata, Teiidae) in Argentina. Cuadernos de Herpetologia, 16, 169-170.

Cabrera, M.R. (2009) Lagartos del centro de la Argentina. Cordoba. Edicion del Autor. 120 pp.

Cabrera, M.R. (2012) A new species of Cnemidophorus (Squamata, Teiidae) from the South American Chaco. Herpetological Journal, 22, 123-131.

Cabrera, M.R. \& Etheridge, R. (2006) New records and type locality restriction for the endemic argentinian lizard Cnemidophorus tergolaevigatus (Squamata: Teiidae). Herpetological Review, 37, 110-111.

Cabrera, M. P.\& Guerra, C. (2006) Tarentola mauritanica. Herpetological review, 37, 362.

Cabrera, M.R. \& Monguillot, J.C. (2006) A new Andean species of Liolaemus of the darwinii complex (Reptilia: Iguanidae). Zootaxa, 1106, 35-43.

Cabrera, M.R. \& Monguillot, J.C. (2007) Reptilia, Squamata, Teiidae, Teius suquiensis: New evidence of recent expansion of this partenogenetic lizard? Check List, 3, 180-184.

Cacciali, P. (2010) Distribución y afinidades biogeograficas de la familia Gymnophtalmidae de Paraguay. Reporte Cientifico de la Facultad de Ciencias Naturales, 1, 10-19.

Cei, J.M. (1974) Two new species of Ctenoblepharis (Reptilia: Iguanidae) from the arid environment of central Argentina (Mendoza Province). Journal of Herpetology, 8, 71-75. http://dx.doi.org/10.2307/1563078 
Cei, J.M. (1978) Homonota darwini macrocephala, n. subsp. del noroeste Argentino (Sauria, Gekkonidae). Publicaciones Ocasionales Instituto de Biologia Animal, Universidad Nacional de Cuyo, Mendoza, Argentina, 4, 1-4.

Cei, J.M. (1986) Reptiles del centro, centro-oeste y sur de la Argentina. Herpetofauna de las zonas áridas y semiáridas. Bolletino Museo Regionale di Scienze Naturali, Torino, Monografie IV, 527 pp.

Cei, J.M. (1993) Reptiles del noroeste, nordeste y este de la Argentina. Bolletino Museo Regionale di Scienze Naturali, Torino, Monografie IV, 949 pp.

Cei, J. M. (1979) Remarks on the South American lizard Liolaemus anomalus Koslowsky, and the synonomy of Phrynosaura werneri Müller (Reptilia, Lacertilia, Iguanidae). Journal of Herpetology, 13, 183-186. http://dx.doi.org/10.2307/1563926

Cei, J.M. \& Roig, V.G., (1974) Fauna y ecosistemas del Oeste árido argentino. Reptiles de la Provincia de Mendoza, I. Deserta, 4, 69-91.

Cei, J.M. \& Videla, F., (2001) Una rara especie de Liolaemus (Reptilia, Tropiduridae) de la herpetofauna cuyana, con distribución trans-cisandina. Multequina 10, 35-42.

Cei, J.M. \& Williams, J.D. (1984) Las colecciones herpetologicas de la expedicion patagonica del Perito Moreno (Marzo-Abril de 1986) y las formas argentinas de Liolaemus del grupo pictus. Revista del Museo de La Plata Seccion Zoología, 13, 183194.

Cei, J.M., Scolaro, J.A. \& Videla, F. (2001) The present status of Argentinean polychrotid species of the genus Pristidactylus and description of its southernmost taxon as a new species. Journal of Herpetology, 35, 597-605. http://dx.doi.org/ $10.2307 / 1565897$

Cei, J.M., Scolaro, J.A. \& Videla, F. (2003) A taxonomic revision of recognized argentine species of the leiosaurid genus Diplolaemus (Reptilia, Squamata, Leiosauridae). FACENA, 19, 87-106.

Céspedez, J.A., Lions, M.L., Alvarez, B.B, \& Schaefer, E.F. (2001) Inventario de anfibios y reptiles del Parque Nacional Chaco, Argentina. Natura Neotropicalis, 32, 163-169.

Chebez, J.C. (2008) Los que se van. Fauna argentina amenazada. Albatros. 320 pp.

Chebez, J.C. (2009) Otros que se van. Fauna argentina amenazada. Albatros. 552 pp.

Chebez, J.C., Rey, N.R. \& Williams, J.D. (2005) Reptiles de los Parques Nacionales de la Argentina. Buenos Aires. L.O.L.A. 76 pp.

Christie, M.I. (2002a) Liolaemus chiliensis (Sauria: Liolaemidae) en el noroeste patagónico. Cuadernos de Herpetologia, 16, 88-90.

Christie, M.I. (2002b) Liolaemus lineomaculatus (Sauria, Liolaemidae) en el noroeste patagónico. Cuadernos de Herpetologia, $16,83-87$.

Christie, M.I. \& Sage, R.D. (2002) Confirmación de Liolaemus tenuis (Iguania: Liolaemidae) en Neuquén, Argentina con notas ecológicas. Cuadernos de Herpetología, 16, 80-82.

Corbalán, V. \& Debandi, G. (2008) La lacertofauna de Mendoza: lista actualizada, distribución y riqueza. Cuadernos de Herpetologia, 22, 5-24.

Corbalán, V., Scolaro, J.A. \& Debandi, G. (2009) A new species of the genus Phymaturus of the flagellifer group from CentralWestern Mendoza, Argentina (Reptilia: Iguania: Liolaemidae). Zootaxa, 2021, 42-56.

Cruz, F.B., Abdala, C.S. \& Scrocchi, G.J. (2012) Los reptiles de La Rioja. Anillaco. CRILAR. 83 pp.

Díaz Gómez, J.M. (2007) Reptilia, Iguania, Liolaeminae, Liolaemus, Puna, Prepuna, and mountain ranges, Northwestern Argentina. Check List, 3, 105-118.

Dinerstein, E., Olsen, D. M., Graham, D. J. , Webster, A. L., Primm, S. A. Bookbinder M. P. \& Ledec, G. (1995) A conservation assessment of the terrestrial ecoregions of Latin America and the Caribbean. The World Bank. Washington D. C., USA. 129 pp.

Doan, T.M. (2003) A new phylogenetic classification for the gymnophthalmid genera Cercosaura, Pantodactylus and Prionodactylus (Reptilia: Squamata). Zoological Journal of the Linnean Society, 137, 101-115. http://dx.doi.org/10.1046/ j.1096-3642.2003.00043.x

Donoso-Barros, R. (1969) Consideraciones nomenclaturales sobre dos lagartijas Argentinas. Boletín Sociedad de Biología de Concepción, 41, 93-94.

Espinoza, R.E., Lobo, F. \& Cruz, F.B. (2000) Liolaemus heliodermis, a new lizard from northwestern Argentina with remarks on the content of the elongatus group (Iguania: Tropiduridae). Herpetologica, 36, 235-244.

Espinoza, R.E. \& Lobo, F. (2003) Two new species of Liolaemus lizards from northwestern Argentina: speciation within the northern subclade of the elongatus group (Iguania: Liolaemidae). Herpetologica, 59, 89-105. http://dx.doi.org/10.1655/ 0018-0831(2003)059[0089:TNSOLL]2.0.CO;2

Etchepare, E.G., M.R. Ingaramo, C. Falcione, R.H. Aguirre, \& C.E. Barrios (2011) Homonota fasciata Dumeril y Bibron, 1839 (Reptilia, Squamata, Phyllodactylidae). Primer registro para la provincia de Corrientes (Republica Argentina). Cuadernos de Herpetología, 25, 21-22.

Etheridge, R. \& Williams, E.E. (1991) A review of the South American lizard genera Urostrophus and Anisolepis (Squamata: Iguania: Polychridae). Bulletin Museum of Comparative Zoology, 152, 317-361

Federico, L. (2000) Geographic distribution. Cnemidophorus lacertoides. Herpetological Review, 31, 52.

Federico, L. \& Cacivio, P.M. (2000) Geographic distribution: Hemidactylus mabouia. Herpetological Review, $31,53$.

Ferraro, D.P. \& Williams, J.D. (2006) Material tipo de la coleccion de Herpetologia del Museo de La Plata, Buenos Aires, Argentina. Cuadernos de Herpetologia, 19, 19-38. http://dx.doi.org/10.1206/0003-0082(2001)343<0001:TESAEO>2.0.CO;2 
Frost, D.R. \& Etheridge, R.E. (1989) A phylogenetic analysis and taxonomy of iguanian lizards (Reptilia: Squamata). Miscelaneus Publication University of Kansas Museum of Natural History 81, 1-62.

Frost, D.R.; Etheridge, R.; Janies, D. \& Titus, T.A. (2001) Total evidence, sequence alignment, evolution of Polychrotid lizards, and a reclassification of the Iguania (Squamata: Iguania). American Museum Novitates, 3343, 1-38.

Frutos, N., Camporro, L. \& Avila, L.J. (2005) Geographic distribution. Cnemidophorus longicauda. Herpetological Review, 36, 336.

Frutos, N., Pérez, C.H.F. \& Avila, L.J. (2008) Geographic distribution: Liolaemus josei. Herpetological Review, $39,239$.

Gallardo, J.M. (1966) Liolaemus lentus nov. Sp. (Iguanidae) de La Pampa y algunas observaciones sobre los saurios de dicha provincia argentina y del oeste de Buenos Aires. Neotropica 12, 15-29.

Gamble, T., Bauer, A.M., Greenbaum, E. \& Jackman, T.R. (2008) Out of the blue: A novel, trans-Atlantic clade of geckos (Gekkota, Squamata). Zoologica Scripta, 37, 355-366. http://dx.doi.org/10.1111/j.1463-6409.2008.00330.x

Gans, C. 2005. Checklist and bibliography of the Amphisbaenia of the world. Bulletin of the American Museum of Natural History, 289, 1-289. http://dx.doi.org/10.1206/0003-0090(2005)289<0001:CABOTA>2.0.CO;2

Genise, J.F. \& Montanelli, S.B. (1991) Primer hallazgo de Hemidactylus mabouia (Moreau de Jones) en la Argentina. Boletín de la Asociación Herpetológica Argentina, 7, 23.

Gimenez, E.M., Ayarragaray, M. \& Manzano, A. (2008) Diversidad y distribución de los reptiles de la Provincia de Entre Ríos, Argentina. Temas de la Biodiversidad del Litoral III F.G. Aceñolaza (Coordinador - Editor) INSUGEO, Miscelánea, 17, 91-107.

Guerreiro, A., Baldoni, J.C. \& Brigada, A.M. (2005) Herpetofauna de la Sierra de las Quijadas (San Luis, Argentina). Gayana, 69, 6-9.

Hedges, S.B. \& Conn, C.E. (2012) A new skink fauna from Caribbean islands (Squamata, Mabuyidae, Mabuyinae). Zootaxa, $3288,1-244$.

Herrera, R., Voglino, D. \& Liotta, J. (2001) Ophiodes intermedius Boulenger, 1984 (Sauria: Anguidae). Cuadernos de Herpetología, 15, 143-144.

Ibargüengoytía, N.R. \& Schulte II, J.A. (2001) Geographic distribution. Diplolaemus darwini. Herpetological Review, $32,57$.

Ibargüengoytía, N.R., Casalins, L.M., Schulte II, J.A., Amico, A.G. \& Sympson, L. (2001) Geographic distribution. Liolaemus lineomaculatus. Herpetological Review, 32, 120.

Juarez Heredia, V.I. (2011) Revision taxonomica y filogenética del grupo de Liolaemus anomalus (Iguania, Liolaemidae) Tesis de Licenciatura en Ciencias Biologicas, Universidad Nacional de Tucuman, Argentina.

Kacoliris, F., Berkunsky, I. \& Williams J.D. (2006a) Herpetofauna of the Impenetrable Great Chaco. Phyllomedusa, 5, 149157.

Kacoliris, F., Horlent, N. \& Williams, J. (2006b) Herpetofauna, Coastal Dunes, Buenos Aires Province, Argentina. Check List, $2,15-21$.

Koslowsky, J. (1895) Dos nuevas lagartijas de la Provincia de Buenos Aires. Revista del Museo de La Plata, 6, 417-420.

Laspiur, A., Acosta, J.C. \& Abdala, C.S. (2007) A new species of Leiosaurus (Iguania: Leiosauridae) from central-western Argentina. Zootaxa, 1470, 47-57.

Lobo, F. \& Lobo, S. (2003) Geographic distribution: Liolaemus yanalcu. Herpetological Review, 34, 262.

Lobo, F. \& Espinoza, R.E. (2004) Two new Liolaemus from the Puna region of Argentina and Chile: further resolution of purported reproductive bimodality in Liolaemus alticolor (Iguania: Liolaemidae). Copeia, 2004, 850-867. http:// dx.doi.org/10.1643/CH-03-241R1

Lobo, F. \& Quinteros, S. (2005a) A morphology-based phylogeny of Phymaturus (Iguania: Liolaemidae) with the description of four new species from Argentina. Papeis Avulsos de Zoologia, 45, 143-177. http://dx.doi.org/10.1590/S003110492005001300001

Lobo, F. \& Quinteros, S. (2005b) Taxonomic studies of the genus Phymaturus (Iguania: Liolaemidae): redescription of Phymaturus patagonicus Koslowsky 1898, and revalidation and redescription of Phymaturus spurcus Barbour 1921. Journal of Herpetology, 39, 533-540. http://dx.doi.org/10.1670/170-04A.1

Lobo, F. \& Abdala, C.S. (2007) Descripción de una nueva especie de Phymaturus del grupo de Phymaturus palluma de la provincia de Mendoza, Argentina. Cuadernos de Herpetología, 21, 103-113.

Lobo, F., Abdala, C.S. \& Valdecantos, S. (2010a) Taxonomic studies of the genus Phymaturus (Iguania, Liolaemidae): description of four new species. South American Journal of Herpetology, 5, 102-126. http://dx.doi.org/10.2994/ 057.005.0205

Lobo, F., R.E. Espinoza, \& A.S. Quinteros (2010b) A critical review and systematic discussion of recent classification proposals for liolaemid lizards. Zootaxa, 2549, 1-30.

Lobo, F., Cruz, F.B. \& Abdala, C.S. (2012a) Multiple lines of evidence show that Phymaturus agilis Scolaro, Ibargüengoytía \& Pincheira-Donoso, 2008 is a junior synonym of Phymaturus spectabilis Lobo \& Quinteros, 2005. Cuadernos de Herpetología 16, 21-27.

Lobo, F., Espinoza, R.E., Sanabria, E. \& Quiroga, L. (2012b) A new Phymaturus (Iguania: Liolaemidae) from the southern extreme of the Argentine Puna. Copeia, 2012, 12-22. http://dx.doi.org/10.1643/CH-11-086

Lobo, F., Nenda, S.J. \& Slodki, D. (2012c) A new lizard of Phymaturus (Iguania: Liolaemidae) from Argentina. Herpetologica, 68, 121-133. http://dx.doi.org/10.1655/HERPETOLOGICA-D-11-00044.1

Lobo, F., Abdala, C.S. \& Valdecantos, S. (2012) Morphological diversity and phylogenetic relationships within a South- 
American clade of iguanian lizards (Liolaemidae: Phymaturus). Zootaxa, 3315, 1-41.

Lopez, C.A. \& Kubisch, E. (2008) Relevamiento in situ de la herpetofauna del Refugio Privado de Vida Silvestre Yacutinga, Provincia de Misiones (Argentina). Aprona Boletin Científico, 40, 1-12.

Lopez, C.A. \& Prado, W. (2008) Relevamiento in situ de la herpetofauna del Refugio Privado de Vida Silvestre El Cachapé, Provincia de Chaco (Argentina). Aprona Boletin Científico, 40, 14-25.

Lopez, C.A. \& Prado, W. (2012) Anfibios y reptiles de Misiones. Guía de Campo. Buenos Aires. Maria Luisa Petraglia de Bolzon Editora. 96 pp.

Martínez Oliver, I. \& Lobo, F. (2002) Una nueva especie de Liolaemus del grupo alticolor (Iguania: Liolaemidae) de la Puna salteña, Argentina. Cuadernos de Herpetologia, 16, 47-62.

Martinez, L.E. (2012) Métodos empíricos para delimitar especies: el complejo Liolaemus bibronii (Squamata: Liolaemini) como ejemplo. PhD Thesis, Universidad Nacional de Cordoba, Argentina.

Martinez, L.E., Avila, L.J., Pérez, C.H.F., Pérez, D.R., Sites Jr., J.W. \& Morando M. (2011) A new species of Liolaemus (Squamata, Iguania, Liolaemini) endemic to the Auca Mahuida volcano, northwestern Patagonia, Argentina. Zootaxa, 3002, 20-30.

Martins, M.B. (1998) Revisão taxonômica e sistemática filogenética do gênero Ophiodes Wagler, 1828 (Sauria, Anguidae, Diploglossinae). Tesis de Doutorado em Biociências (Zoologia), Pontifícia Universidade Católica do Rio Grande do Sul, PUCRS, Brasil.

Minoli, I. \& Avila, L.J. (2011a) Geographic distribution: Liolaemus xanthoviridis. Herpetological Review, 42, 115-116.

Minoli, I. \& Avila, L.J. (2011b) Reptilia, Squamata, Iguania, Leiosauridae, Pristidactylus nigroiugulus, Cei, Scolaro and Videla 2001: New records for Chubut Province and geographic distribution map. Check List, 7, 404-406.

Monguillot, J.C., Cabrera, M.R., Acosta, J.C. \& Villavicencio, J. (2006) A new species of Liolaemus (Reptilia: Iguanidae) from San Guillermo National Park, western Argentina. Zootaxa, 1361, 33-43.

Montero, R. (1996) Lista de las localidades de los Amphisbaenidae de Argentina. Cuadernos de Herpetología, 10, 25-45.

Montero, R., \& Céspedez, J. (2002) New two-poored Amphisbaena (Squamata: Amphisbaenidae) from Argentina. Copeia 2002, 792-797. http://dx.doi.org/10.1643/0045-8511(2002)002[0792:NTPASA]2.0.CO;2

Morando, M., Avila, L.J. \& Sites Jr., J.W. (2003) Sampling strategies for delimiting species: Genes, individuals, and populations in the Liolaemus elongatus-kriegi complex (Squamata: Liolaemidae) in Andean-Patagonian South America. Systematic Biology, 52, 159-185. http://dx.doi.org/10.1080/10635150390192717

Morando, M., Avila, L.J., Baker, J. \& Sites Jr., J.W. (2004) Phylogeny and phylogeography of the Liolaemus darwinii complex (Squamata: Liolaemidae): evidence for introgression and incomplete lineage sorting. Evolution, 58, 842-861. http:// dx.doi.org/10.1111/j.0014-3820.2004.tb00416.x

Morando, M., Avila, L.J., Turner, C.R. \& Sites Jr., J.W. (2007) Molecular evidence for a species complex in the patagonian lizard Liolaemus bibronii and phylogeography of the closely related Liolaemus gracilis (Squamata: Liolaemini). Molecular Phylogenetics and Evolution, 43, 952-973. http://dx.doi.org/10.1016/j.ympev.2006.09.012

Morando, M., Avila, L.J., Turner, C. \& Sites Jr., J.W. (2008) Phylogeography between valleys and mountains: the history of populations of Liolaemus koslowskyi (Squamata: Liolaemini). Zoologica Scripta, 37, 603-618. http://dx.doi.org/10.1111/ j.1463-6409.2008.00350.x

Morando, M., Avila, L.J., Perez, C.H.F., Hawkins, M. \& Sites Jr., J.W. (2012) A molecular phylogeny of the lizard genus Phymaturus (Squamata, Liolaemini): implications for species diversity and historical biogeography of southern South America. Molecular Phylogenetic \& Evolution DOI information: 10.1016/j.ympev.2012.10.019.

Nori, J., Abdala, C.S. \&Scrocchi, G.J. (2010a) Reptilia, Iguania, Liolaemidae, Liolaemus goetschi, Müller and Hellmich, 1938: Distribución extension. Check List, 6, 3-4.

Nori, J., Abdala, C.S. \& Scrocchi, G.J. (2010b) Liolaemus goetschi (Iguania: Liolaemidae): redescription and phylogenetic relationships within the L. boulengeri group. Zootaxa, 2440, 49-59.

Nuñez, H. \& Fox, S.F. (1989). Liolaemus puritamensis, a new species of iguanid lizard previously confused with Liolaemus multiformis (Squamata: Iguanidae). Copeia, 1989, 456-460. http://dx.doi.org/10.2307/1445443

Nuñez, H. \& Jaksic, F. (1992) Lista comentada de los reptiles terrestres de Chile continental. Boletín del Museo Nacional de Historia Natural, Chile, 43, 63-91.

Nuñez, H. \& Scolaro, A. (2009) Liolaemus (donosolaemus) chacabucoense, nueva especie de lagartija para la region de Aisen, Chile (Reptilia, Sauria). Boletín del Museo Nacional de Historia Natural, Chile, 58, 67-74.

Parraga, M.R. (2011) Nueva localidad para Liolaemus wiegmannii (Dumeril \& Bibron, 1837) en la provincia de Salta (Argentina). Cuadernos de Herpetologia, 25, 27.

Pérez, C.H.F. \& Grassini, C.M. (2001) Geographic distribution. Cnemidophorus lacertoides. Herpetological Review, $32,275$.

Pérez, C.H.F. \& Pérez, D.R. (2001) Geographic distribution. Liolaemus bibroni. Herpetological Review, 32, 276.

Pérez, C.H.F. \& Petracci, P.F. (2004) Geographic distribution. Cnemidophorus longicauda. Herpetological Review, $35,187$.

Pérez, C.H.F., López, E.C.G. \& Avila, L.J. (2004) Geographic distribution. Cnemidophorus serranus. Herpetological Review, 35, 408.

Pérez, D.R., Pérez, C.H.F. \& Avila, L.J. (2005) Geographic distribution. Homonota underwoodi. Herpetological Review, 36 , 468.

Pérez, C.H.F., Frutos, N., Morando, M. \& Kozykariski, M. (2008) Southernmost records for Homonota fasciata (Duméril \& Bibron, 1836) in northern Patagonia, Argentina. Herpetozoa, 20, 182-184. 
Pérez, C.H.F. \& Avila L.J. (2011) First record of Liolaemus lentus Gallardo, 1966 (Squamata, Iguania, Liolaemini) in Río Negro province, Argentina. Herpetology Notes, 4, 191-193.

Pérez, C.H.F., Frutos, N., Kozykariski, M., Morando, M. Pérez, D.R. \& Avila, L.J. (2011) Lizards of Rio Negro Province, northern Patagonia, Argentina. Check List, 7, 202-219.

Pincheira-Donoso, D. \& Nuñez. (2005) Las especies chilenas del género Liolaemus Wiegmann, 1834 Iguania Tropiduridae: Liolaeminae). Taxonomía, sistemática y evolución. Publicación Ocasional del Museo Nacional de Historia Natural, Chile 59:7-486,

Pincheira-Donoso, D. \& Scolaro, J.A. (2007) Iguanian Species-richness in the Andes of boreal Patagonia: Evidence for an additional new Liolaemus lizard from Argentina lacking precloacal glands (Iguania, Liolaeminae). Zootaxa, 1452, 55-69.

Pincheira-Donoso, D., Scolaro, J.A. \& Schulte II, J.A. (2007) The limits of polymorphism in Liolaemus rothi: Molecular and phenotipic evidence for a new species of the Liolaemus boulengeri clade (Iguanidae, Liolaemini) from boreal Patagonia of Chile. Zootaxa, 1452, 25-42.

Pincheira-Donoso, D., Scolaro, J.A. \& Sura, P. (2008) A monographic catalogue on the systematic and phylogeny of the South American iguanian lizard family Liolaemidae (Squamata: Iguania). Zootaxa, 1800, 1-85.

Quinteros, S. (2012) Taxonomy of the Liolaemus alticolor-bibronii group (Iguania: Liolaemidae), with descriptions of two new species. Herpetologica, 68, 100-120. http://dx.doi.org/10.1655/HERPETOLOGICA-D-10-00065.1

Quinteros, S. \& Abdala, C.S. (2007) Liolaemus puritamensis Núñez y Fox, 1989 (Iguania, Liolaemidae). Cuadernos de Herpetología, 21, 117.

Quinteros, A.S., Abdala, C.S. \& Lobo, F.J. (2008a) Redescription of Liolaemus dorbignyi, Koslowsky, 1898 and description of a new species of Liolaemus (Iguania: Liolaemidae). Zootaxa, 1717, 51-67.

Quinteros, A.S., Abdala, C.S., Díaz Gómez, J.M. \& Scrocchi, G.J. (2008b) Two new species of Liolaemus (Iguania: Liolaemidae) of central west Argentina. South American Journal of Herpetology, 3, 101-111. http://dx.doi.org/10.2994/ 1808-9798(2008)3[101:TNSOLI]2.0.CO;2

Quinteros, A.S. \& Abdala, C.S. (2011) A new species of Liolaemus of the Liolaemus montanus section (Iguania: Liolaemidae) from northwestern Argentina. Zootaxa, 2789, 35-48.

Rivas, G.A., Molina, C.R., Ugueto, G.N., Barros, T.R., Barrio-Amoros, C.L. \& Kok, P.J.R. (2012) Reptiles of Venezuela: an updated and commented checklist. Zootaxa, 3211, 1-64.

Salas, N.E., Giordana, M.B. \& Di Tada, I.E. (2004) Geographic distribution. Pristidactylus achalensis. Herpetological Review, $35,188$.

Sanabria, E.A., Quiroga, L.B. \& Acosta, J.C. (2005) Geographic distribution. Liolaemus olongasta. Herpetological Review, 36, 337.

Sanabria, E. \& Quiroga, L. (2009) Actualizacion de la herpetofauna del parque provincial Ischigualasto: comentarios sobre su distribución. Cuadernos de Herpetología, 23, 55-59.

Scolaro, J.A. (2005) Reptiles patagónicos sur. Una guía de campo, Universidad Nacional de la Patagonia San Juan Bosco, Trelew. 80 pp.

Scolaro, J.A (2006) Reptiles patagónicos norte. Una guía de campo, Universidad Nacional de la Patagonia San Juan Bosco, Comodoro Rivadavia. $112 \mathrm{pp}$.

Scolaro, J.A. 2010. Redescripción del Neotipo de Phymaturus palluma: un aporte preliminar a la delimitacion de su terra tipica (Reptilia, Sauria, Liolaemidae). Boletín del Museo de Historia Natural, 59, 29-39.

Scolaro, J.A. \& Cei, J.M. (2003) Una excepcional nueva especie de Phymaturus de la pre-cordillera de Chubut, Argentina (Liolaemidae, Iguania, Lacertilia, Reptilia). Facena, 19, 107-112.

Scolaro, J.A. \& Cei, J.M. (2006) A new species of Liolaemus from central steppes of Chubut, Patagonia Argentina (Reptilia: Iguania: Iguanidae). Zootaxa, 1133, 61-68.

Scolaro, J.A. \& Ibargüengoytía, N.R. (2007) A new species of Phymaturus from rocky outcrops in the central steppe of Rio Negro province, Patagonia Argentina (Reptilia: Iguania: Liolaemidae). Zootaxa, 1524, 47-55.

Scolaro, J.A. \& Ibargüengoytía, N.R. (2008) A new fragment for the understanding of the puzzling evolutive process of the Phymaturus genus: a new species of the patagonicus group from Patagonia, Argentina (Reptilia: Iguania: Liolaemidae). Zootaxa, 1939, 38-50.

Scolaro, J.A., Ibargüengoytía, N.R. \& Pincheira-Donoso, D. (2008) When starvation challenges the tradition of niche conservatism: On a new species of the saxicolous genus Phymaturus from Patagonia Argentina with pseudoarboreal foraging behaviour (Iguania, Liolaemidae). Zootaxa, 1782, 48-60.

Scolaro, J.A. \& Tappari, O.F. (2009) Una nueva especie del género Phymaturus del "grupo patagonicus" en los afloramientos rocosos del sudoeste de la provincia de Río Negro, Patagonia Argentina (Reptilia: Iguania: Liolaemidae). Naturalia Patagónica, 5, 80-93.

Scolaro, J. A. \& Pincheira-Donoso, D. (2010). Lizards at the end of the world: Two new species of Phymaturus of the patagonicus clade (Squamata, Liolaemidae) revealed in southern Patagonia of Argentina. Zootaxa, 2393, 17-32

Scolaro, J.A., Mendez de la Cruz, F. \& Ibargüengoytía N.R. (2012) A new species of Phymaturus of the patagonicus clade (Squamata, Liolaemidae) from isolated plateau of southwestern Rio Negro Province, Argentina. Zootaxa 3451: 17-30.

Scrocchi, G.J. \& Giraudo, A.R. (2005) Reptiles de la Reserva El Bagual: Historia natural y paisaje de la Reserva El Bagual, Provincia de Formosa, Argentina. In: Di Giacomo, A.G. y Kapovickas, S.F. (Eds), Temas de Naturaleza y Conservacion 4. Asociacion Ornitologica del Plata, Buenos Aires pp. 155-198. 
Scrocchi, G.J., Abdala, C.S., N. J. \& Zaher, H. (2010) Reptiles de la provincia de Rio Negro, Argentina. Fondo Editorial Rionegrino, Viedma.

Sociedade Brasileira de Herpetologia (2012). A Lista Brasileira de Anfíbios e Répteis. http://sbherpetologia.org.br/checklist/ checklist_brasil.asp. Accessed April, 24, 2012.

Tedesco, M.E. \& Aguirre, R. (1998) Cercosaura ocellata petersi Ruibal, 1952 (Squamata, Gymnophthalmidae). Nuevo registro para la lacertofauna de la Republica Argentina. Cuadernos de Herpetologia, 12, 52.

Torres-Carvajal, O. (2007) A taxonomic revision of South American Stenocercus (Squamata: Iguania) lizards. Herpetological Monographs, 21, 76-178. http://dx.doi.org/10.1655/06-001.1

Townsend, T.M., Mulcahy, D.G., Noonan, B.P., Sites Jr., J.W., Kuczynski, C.A., Wiens, J.J. \& Reeder, T.W. (2011) Phylogeny of iguanian lizards inferred from 29 nuclear loci, and a comparison of concatenated and species-tree approaches for an ancient, rapid radiation. Molecular Phylogenetics and Evolution, 61, 363-380. http://dx.doi.org/10.1016/ j.ympev.2011.07.008

Trefaut Rodriguez, M. (1987) Sistemática, ecologia e zoogeografia dos Tropidurus do grupo torquatus ao sul do Rio Amazonas (Sáuria, Iguanidae). Arquivos de Zoologia, 31,105-230.

Uetz, P. (2012) The Reptile Database. http://www.reptile-database.org. Accessed April, 24, 2012.

Vega, L.E., Bellagamba, P. \& Lobo, F. (2008) A new endemic species of Liolaemus (Iguania: Liolaemidae) from the mountain range of Tandilia, Buenos Aires province, Argentina. Herpetologica, 64, 81-91. http://dx.doi.org/10.1655/06-062.1

Victoriano, P.F., Coronado, T.M. \& Ortiz, J.C. (2010) A multivariate analysis of taxonomic limits in Diplolaemus Bell, 1843. Gayana, 74, 23-36.

Vitt, L.J. \& J.P. Caldwell (2009) Herpetology. An introductory biology of amphibians and reptiles. Third Edition. Academic Press. Massachussets. USA. 697 pp.

Waller, T. (2009) Anisolepis longicauda Boulenger, 1891 (Squamata, Leiosauridae). Primera cita para la provincia de Corrientes, Argentina. Cuadernos de Herpetología, 23, 67.

Williams, J. D. (1988) Hallazgo de Hemidactylus turcicus (Laurent, 1758) (Lacertilia: Gekkonidae) en Argentina. Boletín de la Asociación Herpetológica Argentina, 4, 9-10.

Williams, J.D. (2003) Nuestro Libro Rojo: Lagartija de los Exploradores. Revista de la Fundación Vida Silvestre Argentina, 85, 82-83.

Williams, J. \& Kacoliris, F. (2011) Squamata, Scincidae, Mabuya dorsivittata (Cope, 1862): Distribution extension in Buenos Aires province, Argentina. Check List, 7, 388. 